\title{
Kıbrıs Celvetiliğinde Unutulmuş Bir Mirasın Yeniden Hatırlanışı: Magosa Kutup Osman Efendi Türbe ve Dergâhının İnşa ve İhyası
}

\author{
Mustafa Eyyamoğlu* - Nuran Kara Pilehvarian**
}

Reminiscence of a Forgotten Inheritage in Celvetiyye of Cyprus: The Building and Revival of the Mausoleum and Dervish Lodge of Kutup Osman Efendi in Magosa

Abstract $\square$ This article about the Kutup Osman Efendi Dervish Lodge, located outside of the walls of Famagusta in the Turkish Republic of Northern Cyprus, focuses on the changes the lodge went through especially before the nineteenth century based on the archival documents, engravings, maps and the recent literature. Atpazari Osman Fazlı Efendi (1632-1691), who was among the most salient figures of Celvetiye brotherhood and who dispatched around 150 disciples, including the renowned İsmail Hakkı Bursevi, to various parts of the Ottoman Empire, ended up being exiled to Famagusta where he deceased in 1691 because of his significant degree of intervention in politics in Istanbul. The tomb of this significant figure, who was buried in the outskirts of the Ottoman Graveyard located outside of the walls of the Famagusta, was eventually lost. Seyyid Mehmet Aga, also a member of the Celvetiye brotherhood and a head royal door-keeper, who was appointed to Cyprus as a tax officer (muhassil), found his tomb and built a mausoleum for him. Even though this mausoleum is mentioned in the endowment deeds, there is no mention of the masjid built next to it. Similarly, the fact that there was a dervish lodge in that location previously goes unnoticed. This article examines the mausoleum and the construction around it, the historical evolution of the area since the conquest of Cyprus, and it analyzes centuries-long archeological/cultural layers while observing the transformation of this previously Christian site into an Islamic one.

Keywords: Cyprus, Dervish Lodge of Kutup Osman Efendi, Ottoman Heritage, Turkish Culture in Cyprus, Ottoman Architecture of $19^{\text {th }}$ Century in Cyprus.

* Yakın Doğu Üniversitesi.

** Yıldız Teknik Üniversitesi. 


\section{Giriş}

Makalenin konusunu teşkil eden Kutup Osman Efendi'nin (1632-1691) Magosa'daki dergâhı, Kıbrıs'ta Osmanlı siyasi ve sosyal örgütlenmelerinin öncüsü olan dergâhlardan biridir. Bugünkü dergâha adını veren Osman Fazlı Efendi, 17. yüzyılda yaşamış dönemin önemli Celveti şeyhlerinden olup, tasavvufî mertebesine ve yaşamış olduğu bölgeye göre, Osman Fazlı Efendi, Emir Efendi, Emir Sultan, Atpazarî, Atpazarî Şeyh Osman Efendi ve Kutup Osman Efendi gibi farklı isimlerle anılmaktadır. Hakkında en detaylı bilgiler halefi ve damadı olan İsmail Hakkı Bursevi'nin Tamamü'l-Feyz adlı eserinden edinilmektedir. ${ }^{1}$

Osman Fazlı Efendi Bulgaristan'ın Şumnu kasabasında 19 Zilhicce 1041 (7 Temmuz 1632) de doğmuştur. İlköğrenimini onyedi yaşına kadar Şumnu'da babası Fethullah Efendi'nin yanında yapmıştır. Şumnu'da iken bir mecliste işittiği şiirlerin tesirinde kalarak anne ve babasından ilim ve tahsil için izin alan Osman Efendi dönemin önemli bir eğitim merkezi olan Edirne'ye gider. Edirne'de Şumnu'da iken şöhretini duyduğu Aziz Mahmud Hüdai'nin halifelerinden olan Saçlı İbrahim Efendi'ye intisap eder. Kısa bir süre sonra Edirne'den ayrilarak İstanbul'a gider ve Zakirzade Abdullah Efendi'ye intisap eder. Osman Fazlî Efendi'nin tarikat silsilesi Zakirzade Abdullah Efendi kanalı ile Celvetiyye Tarikatı'nın piri olan Aziz Mahmud Hüdayi'ye ulaşmıştır. Zeyrek Camii'ne bitişik olan Zakirzade Tekkesi'nde kaldığı sürede günlerini ilim öğrenerek şeyhine hizmette bulunarak geçiren Osman Fazli Efendi, Zakirzade'nin yirmisekizinci ve son halifesidir.

Tasavvufî eğitimini tamamlayarak Aydos kasabasına halife olarak tayin edilen Osman Efendi tayin beratını almak için dönemin sadrazamı Köprülü Mehmet Paşa tarafindan imtihan edilir ve kendisine Sa'duddin Taftazani'nin Şerhu'l-Akaid adlı eserinden bir bölüm okutularak beratını alır. Bir müddet Aydos'ta vaaz ve tedrisle meşgul olduktan sonra Filibe’ye gider ve burada şeyhlik yapmaya başlar. Filibe'de on beşyıl kadar bir süre şeyhlik yapmıştır.

İstanbul'da yaşadığı dönemde, dönemin önemli vezirlerinden olan Fazıl Ahmet Paşa tarafından hürmet ve itibar gören Osman Efendi, Fazıl Ahmet Paşa’nın

1 Giriş’te Osman Fazlı Efendi'nin hayatına dair bilgiler şu çalışmalardan özetlenmiştir: Sakıb Yıldız, "Atpazarî Osman Fazlı", TDV İslâm Ansiklopedisi (DİA), 1991, IV, 83-85, Ali Namlı, "İsmail Hakkı Bursevi ve Tamâmü-l Feyz Adlı Eseri" (yüksek lisans tezi), Marmara Üniversitesi, 1994, s. 8; Ali Namlı, "İsmaîl Hakkı Bursevî”, TDV İslâm Ansiklopedisi (DİA), 2001, XXIII, 102-106; Muhammet Bedirhan, "Osman Fazlî Atpazarî: Hayatı-Eserleri ve Tasavvufî Görüşleri” (yüksek lisans tezi), Marmara Üniversitesi, 2006, s. 3. 
ölümü üzerine sadarete getirilen Merzifonlu Kara Mustafa Paşa’nın da çevresinde yer alır. Kara Mustafa Paşa Avusturya ile 1664 'te yirmi yıllığına imzalanan barış antlaşmasının yenilenmesinden yana değildir. Kutup Osman Efendi ise barışın bozulmasını istemeyenler safındadır ve devlet çıkarları için savaşa girilmemesi gerektiğini bildiren bir mektup yazar ve sadrazam Kara Mustafa Paşa’ya gönderir. Bu hadise şeyhliğinin yanı sıra devlet işleri ile de yakından ilgilenen Osman Fazlı Efendi'nin saray ve çevresinde etkili bir figür olduğunu göstermektedir.

Sultan IV. Mehmet tarafından vaaz ve nasihatlerde bulunması için Edirne'ye davet edilen Osman Fazlı Efendi, Edirne'ye gider ve nasihatleri sırasında devletin içinde bulunduğu durumdan sultan ve vezirlerin sorumlu olduğu fikrini belirtir. Dönemin Sadrazamı Kara İbrahim Paşa almış olduğu eleştirilerden dolayı Osman Fazlı Efendi'yi sürgün ettirmek için teşebbüslerde bulunur. İbrahim Paşa’nın çabaları neticesinde Osman Fazlı Efendi memleketi olan Şumnu’ya sürgün edilmiştir. Çalkantılı siyasi olaylar neticesinde Kara İbrahim Paşa’nın görevden azledilerek yerine Bosnalı Süleyman Paşa'nın gelmesiyle 3 aydır sürgünde olan şeyh geri çağırılır itibarı iade edilir. Görüşleri ve nasihatlerindeki açık sözlülüğü ile dikkat çeken Osman Fazlı Efendi IV. Mehmet'ten sonra tahta çıan II. Süleyman'ın hürmetini kazanarak zaman zaman saraya ulema ile yaptığı toplantılara çağrılır.

Osman Fazlı Efendi'ye ikinci sürgün emri 20 Şevval 1101 (27 Temmuz 1689) tarihinde verilir. Osman Fazlı Efendi ailesi ve sevenleri ile vedalaştıktan sonra son sürgün yeri olan Magosa’ya doğru yolculuğa çıkar. Osman Fazlı Efendi ve ona eşlik edenler Lefkoşa'ya vardıklarında dönemin valisi Ahmed Paşa, Kıbrıs'ta Mevlevi tarikatına mensup olan kadı ve bir takım şehir eşrafı tarafından karşılanırlar. Vali Ahmed Paşanın evinde misafir edildikten sonra asıl sürgün yeri olan Magosa'ya yola çıan Osman Fazlı Efendi İstanbul'dan ayrıldıktan yirmi iki gün sonra Magosàya varır (18 Ağustos 1689). Şeyhin ikameti için Magosảda tayin edilen Lefkoşavi Mahmud Ağa'nın evinde kalır. Bu esnada şeyhin Anadolu ile iletişiminin devam ettiği anlaşılmaktadır.

Bursa'da olan müridi İsmail Hakkı Bursevi'ye Aralık 1690 yılında mektup göndererek Kıbrıs'a gelmesini ister. Şeyhinin mektubunu alan Bursevi 4 Rebiyülevvel 1102 de (9 Aralık 1690) Osman Efendi’nin küçük oğlu Mustafa, Osman Dede, Yakup Dede, Yahya Dede ile beraber Magosa'ya gider. Bursevi şeyhinin yanında 17 gün kaldıktan sonra Yakup Dede ve Yahya Dede ile geri döner. Oğlu Mustafa ve Osman Dede Kıbrıs'tan ayrılmayarak Fazlı Efendinin yanında kalırlar. 
Magosa'ya yerleşmesinden sonra sağlık durumu iyice bozulan Osman Fazlı Efendi hummaya tutulmuştur. Hicri 17 Zilhicce 1102 (11 Eylül 1691) Salı günü vefat etmiştir. Kutup Osman Efendi’nin vefatında oğlu Mustafa Efendi, Osman ve Ali Dede Kıbrıs'tadır. Kutup Osman Efendi'nin vasiyeti üzerine vefatından sonra Osman Dede Bursevi'nin yanına dönmüş ve vefatı ile ilgili bilgileri İsmail Hakkı Bursevi'ye anlatmıştır. Bu sayede Bursevi Tamamül-Feyz adlı eserdeki mevcut bilgileri birinci ă̆ızdan dinleyerek kaleme almıştır.

Cenazesi Kale dışında bulunan musallaya çıkarılmış ve cenaze namazı kılındıktan sonra yel değirmenlerinin yakınındaki kabristanda Evliyalar Tepesi denilen bölgedeki mezarlığa defnedilmiştir. Bursevî, Kutup Osman Efendi’nin şöhretten hoşlanmadığını ve kabrinin üzerinin de açık bırakılmasını vasiyet ettiğinden söz etmektedir. Üzerine yapı inşa edilmeyişinden kabrin yeri zamanla kaybolmuştur.

19. yüzyıl başlarında Kıbrıs’a muhassıl olarak atanan saray kapıcıbaşılarından ve Celveti tarikatına mensup olan Seyyid Mehmet Ağa İstanbul'daki Celveti velilerinden böyle bir kişinin Kıbrıs'ta medfun bulunduğunu öğrenerek adaya geldiğinde Kutup Osman Efendi'nin mezarının bulunması için çalışmalara başlamış, 80 yaşında Salhore Hatun isimli bir kadının bilgilerinden yararlanarak yapılan kazı sonucunda Kutup Osman Efendi'nin Celveti sikkeli mezar taşı bulunmuş ve üzerine türbe inşa ettirilmiştir. Türbe hakkında bilinen önemli kaynaklardan biri Lefkoşa Mevlevihane'si şeyhlerinden Feyzullah Dede'nin eseri olan ve günümüzde Magosa Canbulat Müzesi'nde sergilenen ahşap kitabedir. ${ }^{2}$ Tekke/Türbenin tarihçesi ile ilgili bir diğer belge Seyyid Mehmet Ağa Vakfiyesidir. Kıbrıs'ta yaptırmış olduğu vakıfları ayrı vakfiyede ve zeyiller ekleterek tescil ettiren Seyyid Mehmet Ağa’nın ilk vakfiye tarihi Hicri 19 Cemaziyülevvel $1242 \operatorname{dir}\left(19\right.$ Aralık 1826). ${ }^{3}$

Kuzey Kıbrıs Milli Arşiv ve Araştırma Dairesi'nde de bir kopyası bulunan H. 1242/M. 1826 tarihli vakfiyesinden; Seyyid Mehmet Ağa’nın Kutup Osman Efendi'nin türbesini müceddeden (yeniden) inşa ettirdiği ve yanında bulunan mescitte imamet ve tedris ile meşgul olan bir görevliye de aylık 30 kuruş vazife tahsis ettiği anlaşılmaktadır. ${ }^{4}$ Gerek Seyyid Mehmet Ağa Vakfiyesinden gerekse Kıbrıs Milli Arşiv ve Vakıflar İdaresi arşivinde bulunan kayıtlardan türbe dışında

2 Magosa Canbulat Müzesinde bulunan Türbe kitabesinin yazarı Feyzullah Dede, tekkenin Kıbrıs'a muhassıl olarak atanan Dergâh-ı Ali kapıcıbaşılarından Seyyid Mehmet Ağa tarafından yaptırıldığını belirtmektedir.

3 Vakıflar Genel Müdürlüğü Arşivi (VGMA), Defter No. 989, s. 209.

4 VGMA, d. 989, s. 210-211. 
aynı yerde bir Tekke/Mescit olduğu belirlenmektedir. Şeyh evi, konaklama birimleri ve bir mescitten oluşan tekkenin adına araştırma yapılan arşivlerde rastlanmamıştır. Lala Mustafa Paşa Vakfiyesi içerisinde yer alan (Evahir-i Cemaziyelahir 981) 1573 Ekim sonu tarihli bir emirname dışında bu dergâhın mevcudiyetine veya kuruluşuna ait herhangi bir kayıt ya da vakfiyeye rastlanmamaktadır. Bu vakfiyede Sultan II. Selim Han'ın fermanı ile bir Tekke/Mescit inşa edildiğine ilişkin bilgiler mevcuttur.

Tekke/Dergâh yapılarının içinde bulunduğu mezarlık arazisi, 19. yüzyıl sonlarından başlanarak İngiliz sömürge yönetimi döneminde ortadan kaldırılmış, arazisinde yeni düzenlemeler yapılarak Namık Kemal Lisesi Tekke'nin arazisine inşa edilmiştir. Yapılan bu düzenlemeler, mezarlık ve tekkenin bulunduğu oldukça geniş olan arazisinin parçalanmasına, bütünlüğünün bozulmasına, vakıflarının gelirlerinin kaybolmasına, görevlilerinin de gelirlerinin kesilmesiyle tekke yapılarının asli halinin değişmesine ve bir süre sonra bakımsızlık ve terk edilmekle özgünlüğünü, işlerliğini yitirmesine neden olmuştur. Çalışma kapsamında Kutup Osman Efendi Tekkesi olarak anılan yapılar topluluğu, tarihsel süreç içerisinde geçirmiş olduğu değişimleri, arşiv belgelerinde mevcut tarihi bilgiler ışı̆̆ında ortaya koyarak ele alınacaktır.

\section{Kutup Osman Efendi Tekke/Dergâhı Günümüze Ulaşan Yapılarının Mimari Açıdan İncelenmesi}

Konu ile ilgili mevcut kaynaklarda tümü 1826 'da ve daha sonrasında inşa edilmiş gibi tanımlanan Kutup Osman Efendi Türbe/Tekkesi; türbe, mescit, konaklama birimleri, mutfak, hamam yapılarından oluşmaktadır (Plan 1). Yapılar plan düzeni, duvar örgü tekniği ve malzeme açısından incelendiğinde, mevcut alandaki yapıların değişik dönemlerde inşa edilmiş parçalardan oluştuğu görülmektedir. Gerek tarihleme, gerek mekân işlev ilişkileri gerekse yapısal bakımdan bütünlüğünü kaybetmiş olan yapılar topluluğunda zamanla yapılan değişikliklerin izleri açıkça görülmesine karşın günümüze dek dergâh alanında bir kazı yapılmadığından özgün yapıların mimari durumu çok net anlaşılmamaktadır.

Günümüzde Kuzey-Doğu cephesinde üzeri beşik tonoz ile örtülü bir mekândan girilen giriş ve mutfak kısmının batısında üzeri kubbe ile örtülü bir mekân onun kuzey cephesinde üzeri kubbe ile örtülü türbe, batı cephesinde mescit bulunmaktadır (Resim 1). Türbe ve mescit arasındaki mekândan avluya çıkış bulunmaktadır (Resim 2). Üzeri 3 kubbe ve bir tonoz ile örtülü bu kısım plan şeması 
olarak 13. yüzyıldan itibaren Anadolu ve Balkanlarda görülen Zaviye adı ile anılan yapılara benzemektedir. ${ }^{5}$ Avlunun Doğu cephesinde günümüzde Magosa Halk Kütüphanesi olarak işlevlendirilmiş bulunan önü revaklı 5 tane mekân bulunmaktadır. Avlunun Güney cephesinde 4 mekânla önü revaklı bir yapı bulunmaktadır. Avlunun batı cephesinde bulunan Namık Kemal Lisesi ile ayırıcı duvara yaslanmış vaziyette üzeri kubbe ile örtülü bir hamam bulunmaktadır.

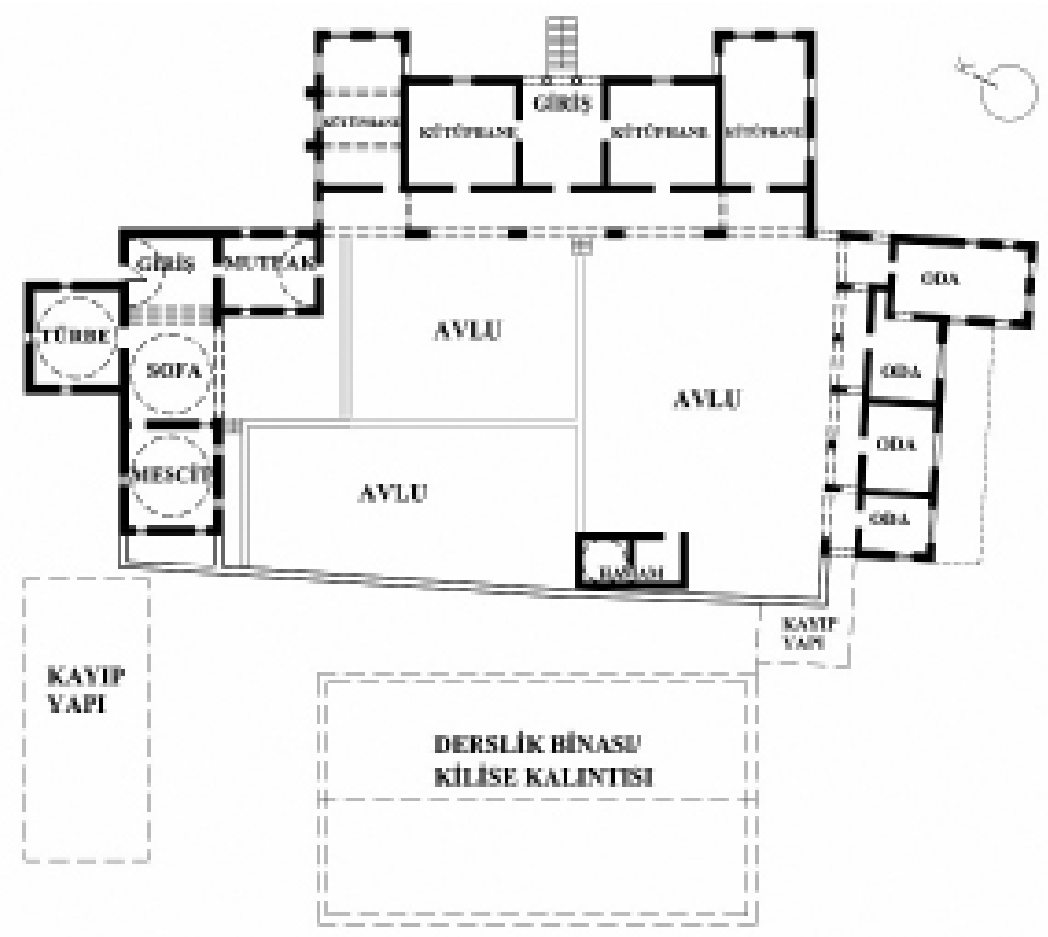

\section{PLAN}

Plan 1. Kutup Osman Tekkesi Vaziyet Planı (Mustafa Eyyamoğlu).

Dergâh yapıları 4 ayrı bölümde ele alınarak değerlendirilebilir. Kutup Osman Efendi Türbesi'nin bulunduğu kuzey kanadını oluşturan bölüme, kuzeydoğu köşesinden basık kemerli kapıdan girilmektedir. Dikdörtgen hacimde olan girişin üzeri beşik tonozla örtülü olup dışarıda sıra dışı bir şekilde yarım tonoza dönüşmektedir (Resim 1). Dışarda yarım tonoz olmasına karşın, içeride beşik

5 Türkân Acar, “Tabhaneli Camilerin Tipolojisi Üzerine Bir Deneme”, Süleyman Demirel Üniversitesi Fen Edebiyat Fakültesi Sosyal Bilimler Dergisi, 208 (2013), s. 303. 
tonoz ile örtülü mekân kuzey-güney istikametine devam etmekte ve basık bir kapı ile günümüzde mutfak olarak kullanılan mekâna geçilmektedir. Magosa şehrine giden Cafer Paşa Su Yolu’nun doğu köşesinden geçip devam eden giriş mekânının doğusu ve batısında ikişer pencere bulunmakta ve güney ucundaki kapı ile iç avluya bağlanmaktadır. Yapı teknolojisi açısından uyumsuzlukların yanısıra mekânlar arası zeminlerde kot farkları bulunmaktadır. Zeminlerdeki bu farklılıkların bir kısmı sonradan dolgu gibi görülmektedir. ${ }^{6}$

Basık kemerli girişten hemen sağa (batıya) doğru kemer vasıtası ile sofa işlevinde olan kubbeli kısma geçilmektedir. Sofanın güneyi kemerle avluya açılmakta olup, kuzeyinde Kutup Osman Efendi'nin türbesi, batısında ise mescit bulunmaktadır. Sofa, türbe ve mescit bölümleri ayrı ayrı birer kubbe ile örtülmüş kare planlı tipik şemaya sahiptir (Resim 3). Kubbelerden kare plana geçişler pandantiflerle sağlanmıştır.

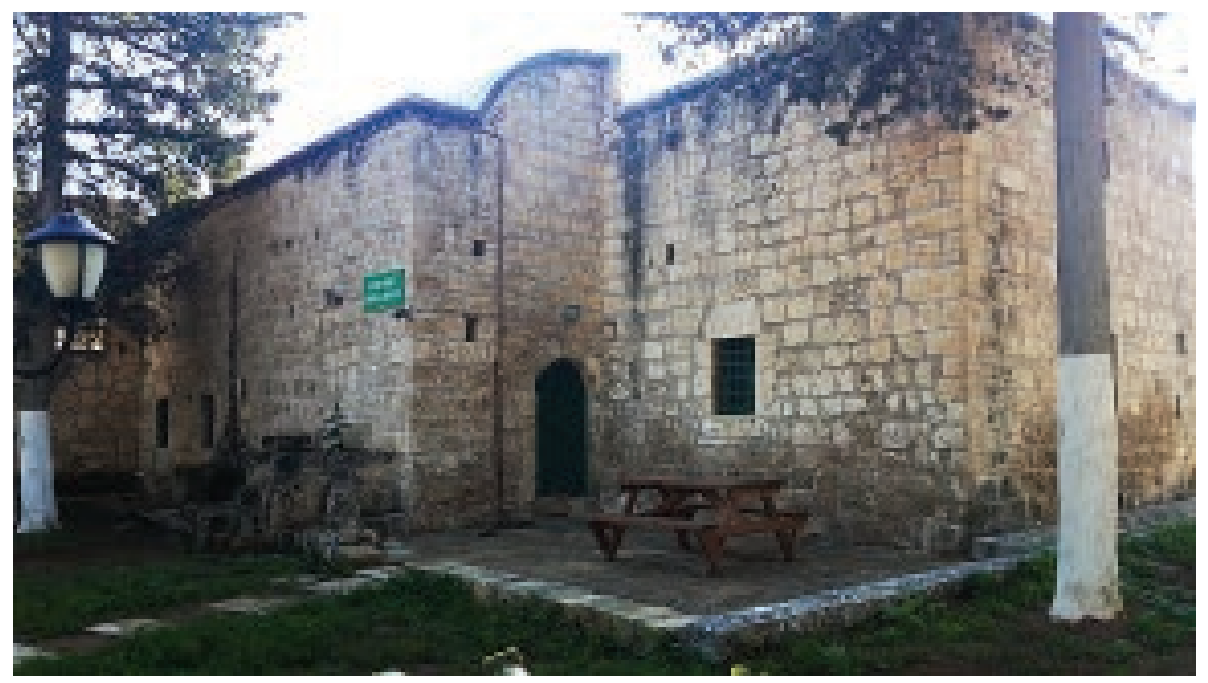

Resim 1. Türbe Girişi (Tonozlu Bölüm, M. Eyyamoğlu).

6 İbrahim Numan, "Kutub Osman Tekkesi Binaları Hakkında”, Sanatta Anadolu-Asya Ilşkileri: Prof.Dr. Beyhan Karamăgaraliya Armă̆an (Ankara: Hacettepe Üniversitesi Yayınları, 2006), s. 346. 


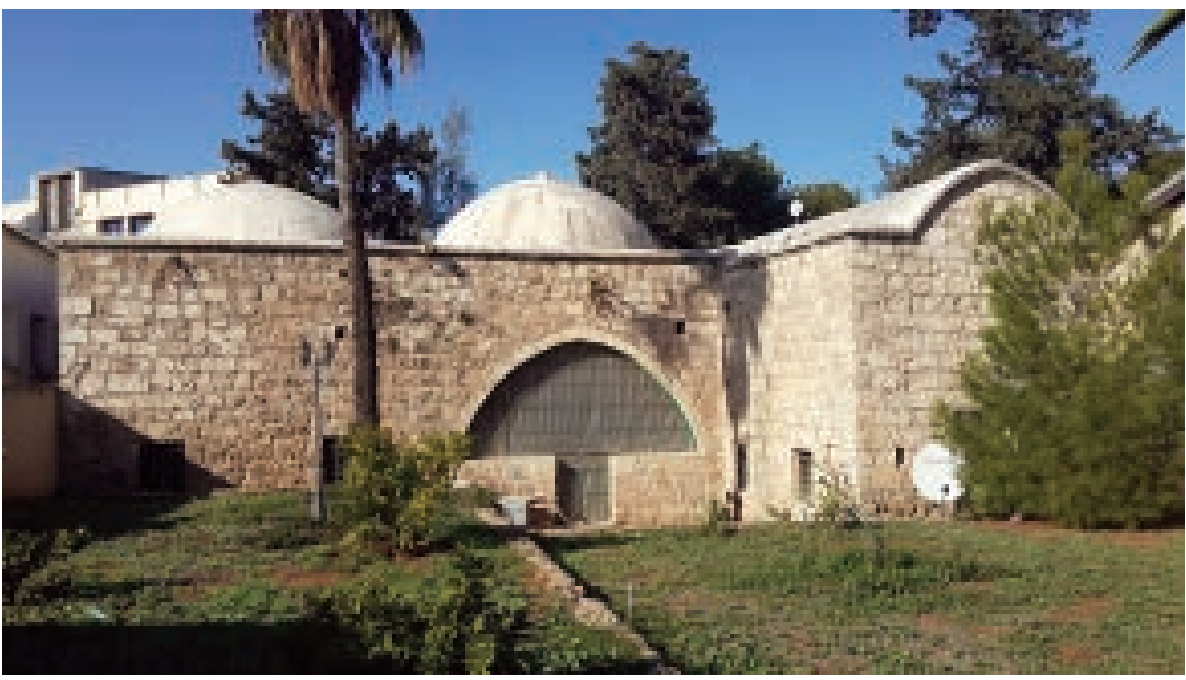

Resim 2. Avluya Açılan Sofa (M. Eyyamoğlu).

Sofanın kuzeyinde bulunan Kutup Osman Efendi'nin türbesinde bitkisel motifler ile bezenmiş küçük bir niş yer almakta olup doğu, batı ve kuzey cephelerinde birer pencere bulunmaktadır (Resim 4). Sofanın batısında bulunan mescit bölümünde, sade bir niş biçiminde mihrap sağında ve solunda birer pencere bulunmaktadır. Kuzey cephesinde tek, batı cephesinde iki adet pencere bulunmaktadır.

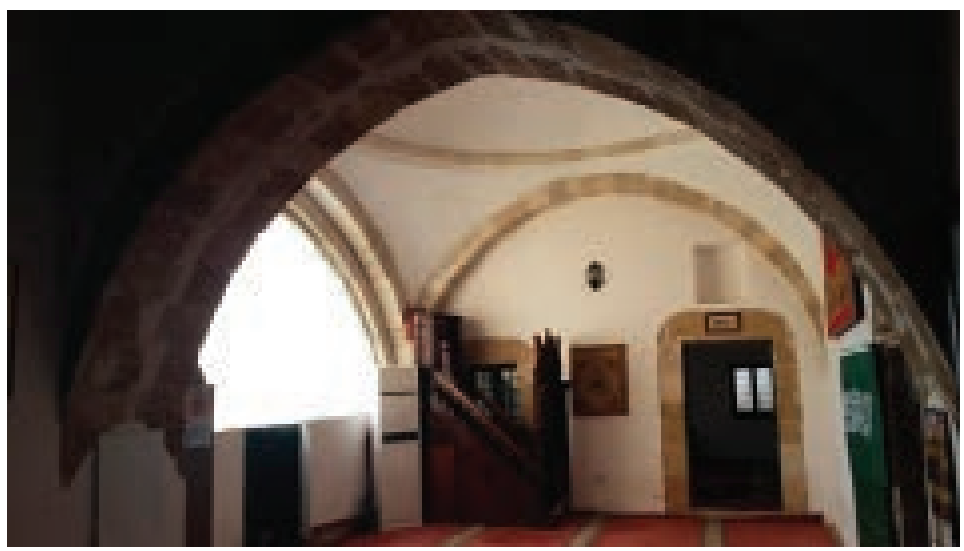

Resim 3. Sofa, Mescit Girişi, Sağda Türbe Girişi (M. Eyyamoğlu). 


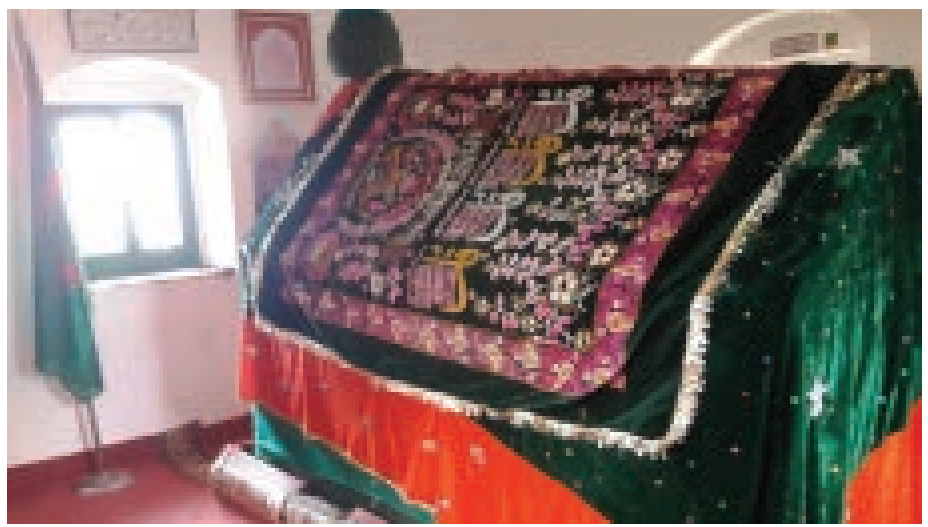

Resim 4. Türbe (M. Eyyamoğlu).

Sofadan avluya geçişi sağlayan kemer açıklı̆ı günümüzde bir metre yükseklikte bir duvar ile doldurularak ortadan bir geçiş bırakılmış vaziyettedir. Avlu zemin kotu türbe ve mescit bölümünden daha yüksek bir seviyededir bu da avlunun sonradan doldurulmuş olduğunu düşündürmektedir (Resim 2).7

Yapıların doğu kanadına ana giriş olduğu izlenimini veren 3 adet kemeri bulunan merdivenli girişten girilmektedir. Girişin Sağ ve sol uçları dışarı uzanarak U şeklindeki planı oluşturmaktadır. Sağ kolda zemin katta dışardan girişi olan ahır olarak kullanıldığ 1 izlenimini veren bir mekân mevcuttur (Resim 5). Basamakl girişte eyvan biçiminde sonradan kapatıldığı anlaşılan sofa vardır. Doğu kanadının orta bölümü oluşturan bu sofanın sağında ve solunda ikişer oda bulunmaktadır. Bu odaların iç avluya açılan revaklı kısımları 5 adet kemerden oluşmaktadır. Sağ ve sol uçlardaki kemerler orta kemerlerden daha yüksek ve sivridir kullanılan malzeme taştır (Resim 6).

7 Kıbrıs Vakıflar İdaresi arşivinde bulunan 67 nolu dosya gömlek 1619 numara ile kayıtlı 1894 tarihli 20 adet belgede tamirler için gerekli malzeme listeleri bulunmaktadır. Belgelerde sözü edilen toprak malzeme avluda yapılan dolgu için getirilmiş olduğunu akla getirmektedir. Kıbrıs Vakfilar İdaresi (KVİ), Dosya No: 67, Gömlek No: 1619. 


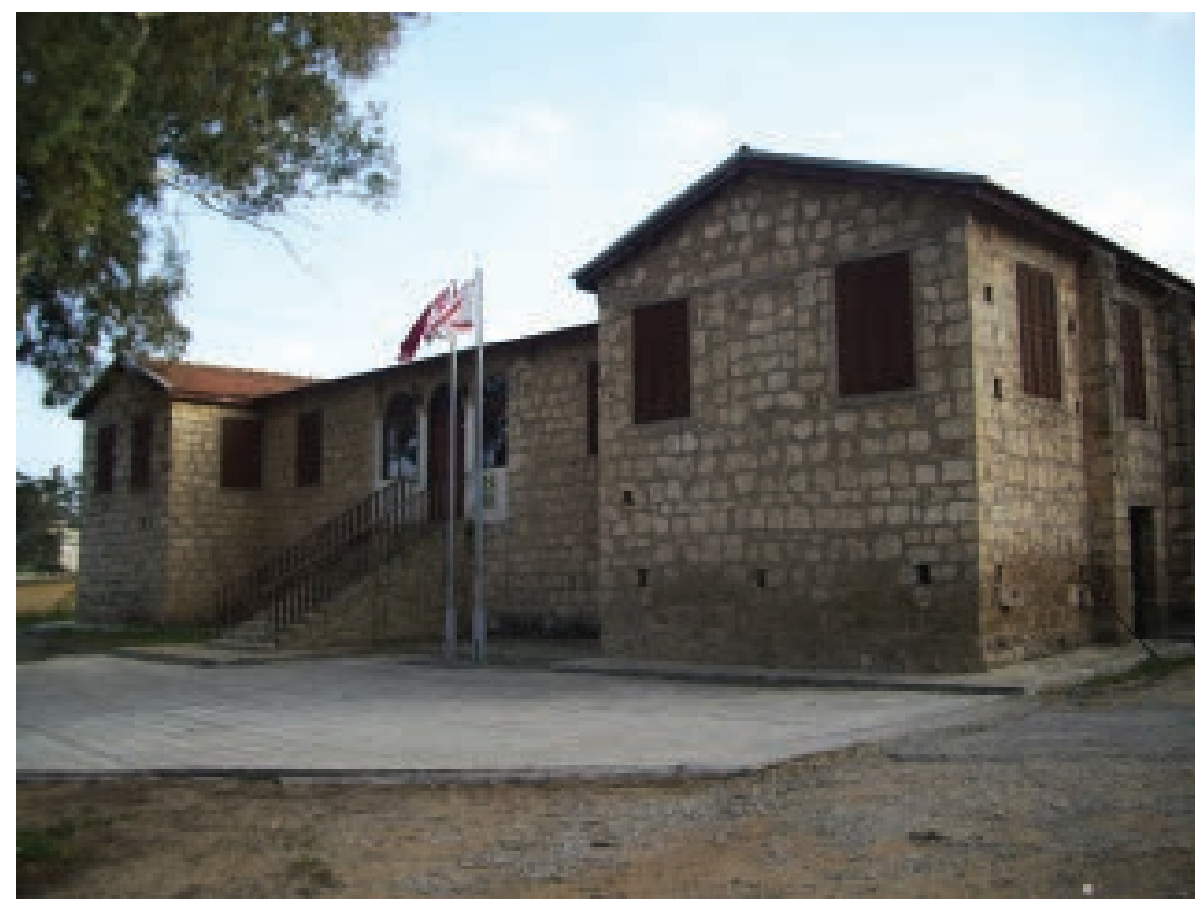

Resim 5. U planlı doğu kanadı, ana giriş ve sağ kolda ahır (M. Eyyamoğlu).

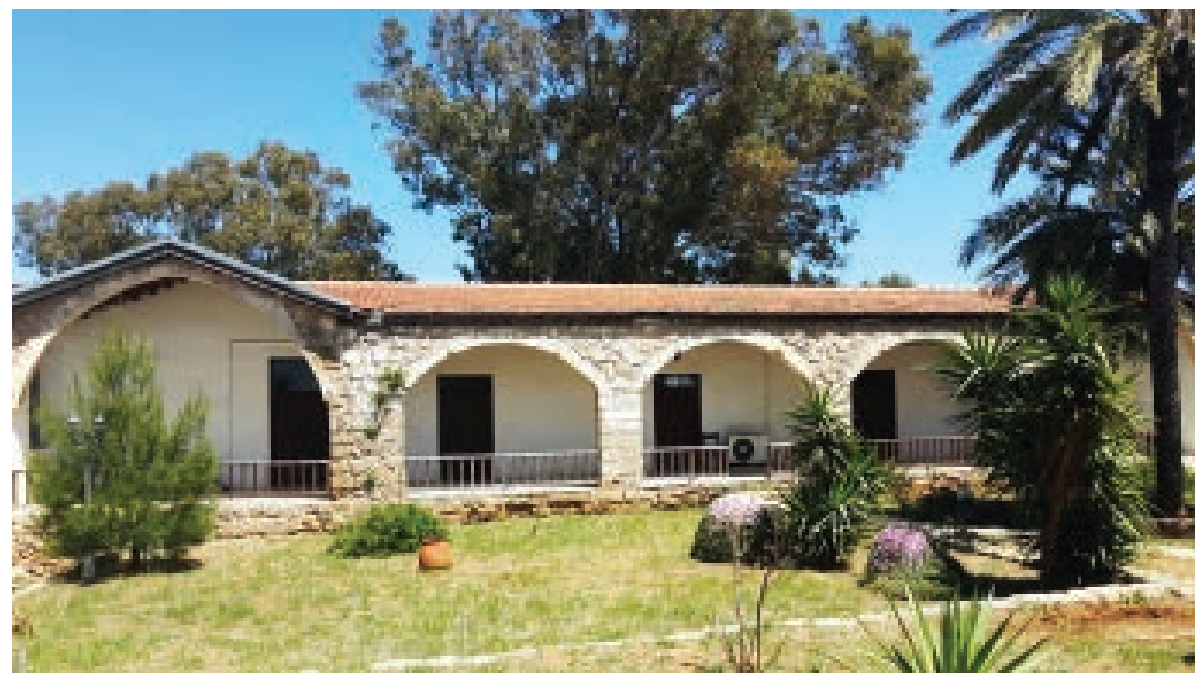

Resim 6. Doğu kanadın avluya bakan revaklı cephesi (M. Eyyamoğlu). 
Yapının güney kanadı avluya bakan altı adet sivri kemerli revaktan oluşmakta ve doğu kanadından düşük kuzey bölümünden ise yüksek bir seviyededir. Yapı 4 farklı odadan müteşekkildir. Doğu uçtaki oda, aks düzenini bozarak güney istikametine doğru çıkıntı yapar durumdadır. Avluya bakan kemer kaideleri doğu bölümünden tamamen farklı üsluptadır. Kıbrıs genelinde diğer şehirlerde görülen orta çağ yapılarındaki üsluba benzemektedir. Buradaki revak kemeleri ise taş sütunlar üzerine oturmaktadır (Resim 6 ve 7).

Namık Kemal Lisesi tarafından inşa edilen, hamam arkasındaki derslik binasının (Resim 8) eski haritalarda görülen dergâhın batı kanadında bulunan yapılar üzerinde olduğu açıkça bellidir (Harita 1). Derslik binasının cephelerinde görülen eski duvar kalıntıları bunun kanıtıdır. Derslik binasının hemen ardında dergâh haremine ait olduğu anlaşılan kare planlı üzeri kubbe ile örtülü hamam ve yanında kare planlı bir kü̧̈ük bir giriş kısmı bulunmaktadır (Resim 8).

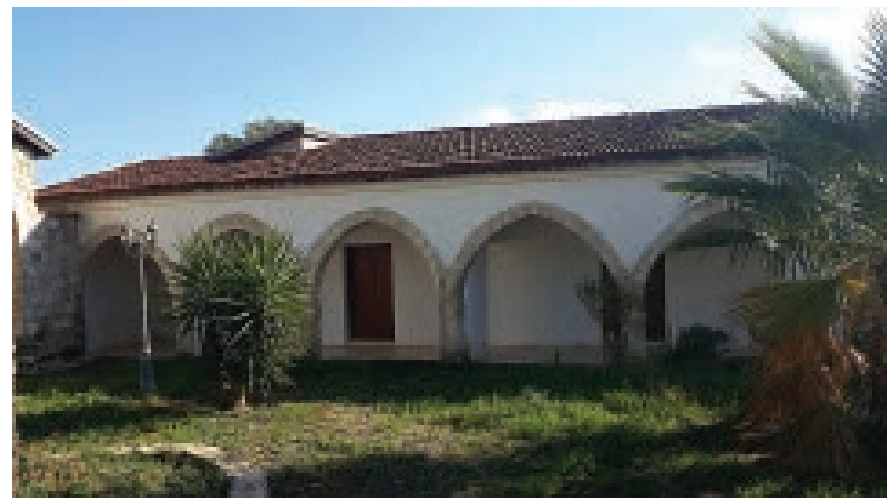

Resim 6. Batı Kanadın Avlu Cephesi (M. Eyyamoğlu).

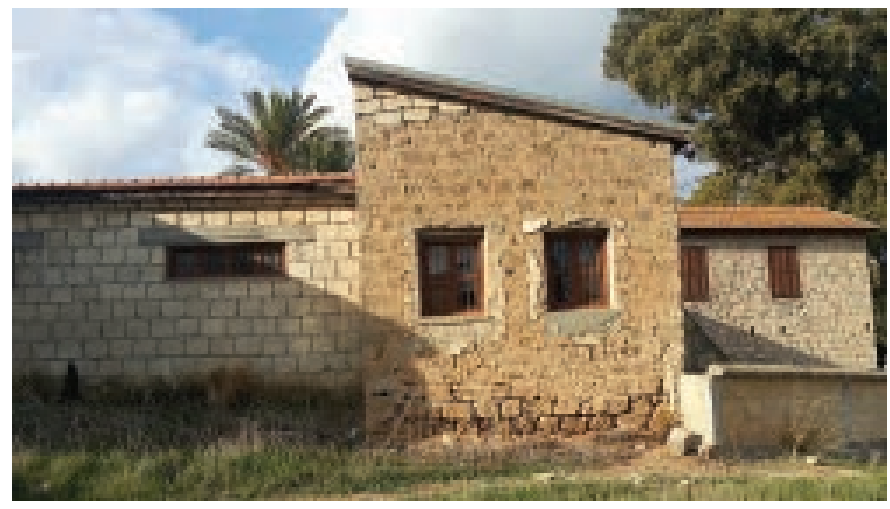

Resim 7. Doğu uçta çıkma mekan (güney) (M. Eyyamoğlu). 


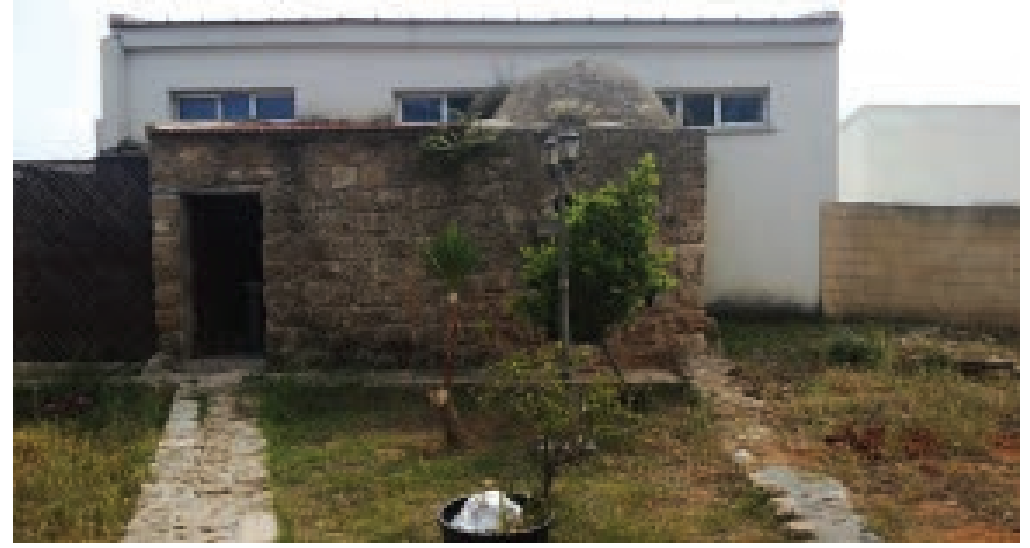

Resim 8. Hamam ve Arkada Derslik Binası (M. Eyyamoğlu).

Dergâh binalarının doğu ve güney bölümlerini oluşturan revaklı kısımlar 2004 yılından itibaren K.K.T.C. Kültür Dairesi kullanımına verilmiş ve Magosa Halk Kütüphanesi olarak kullanılmaktadır. Yakın tarihe kadar atıl vaziyette bulunan tekke binaları beton malzeme ve çimento harcı kullanılarak onarımdan geçmiş ve binalarda izlenebilecek olan birtakım özgün veriler de böylece kaybolmuştur. Türbe bölümünde yapılan düzenlemeler ile mekân ziyaret ve ibadet edilebilecek duruma getirilmiş fakat mimari planda bir bütünlük arz eden avlu, doğu kanadı ve güney kanadı ile irtibatı kesilmiştir. Mevcut haritalarda batı kanadında önceden var olduğu izlenen yapılar üzerine inşa edilen derslikler özgün plan şemasının kaybolmasına neden olmuştur (Harita 1).

Tarihsel süreçte mekânlar arasında bulunan yapı, malzeme, duvar örgüsü ve kot farklılıkları mekânların özgün işlevlerinin saptanabilmesini olanaksız hale getirmektedir. Günümüzde Canbulat Müzesi'nde sergilenen, ahşap yapı kitabesinden edinilen bilgiye göre; Kıbrıs muhassılı Seyyid Mehmet Ağa’nın kaybolan kabri bularak, üzerine bir türbe yaptırmış olduğu dışında binalar hakkında aydınlatıcı kayıt bulunmamaktadır.

Araştırma süresinde tekke binaları hakkında ulaşılabilen resmi kayıtlı tek vakfiye Seyyid Mehmet Ağa Vakfiyesidir. KKTC Girne Milli Arşiv ve Araştırma Dairesinde kopyası bulunan Müceddet Rumeli (3) 989 numaralı defterin 209. sayfasında "Dergâh-1 âli Kapıcıbaşlarından Kıbrıs Muhassılı Es-Seyyid El-Hac Mehmed Ağa" ismi ile kayıtlı vakfiyesinde konu ile ilgili olan kısımda;

“[...] ve Kal'a-i Magosa kurbünde Fazl-1 İlâhî Kutub Osman Efendi kuddisesırruhû hazretlerinin bâ-avni ve tevfik-i ilâhî müceddeden binâ ve vakf eylediği türbe-i 
şerîfesi ve ittisâlinde mescid-i şerîfde ulemâdan olup imâmet ve tedrîs ile meşgûl olan efendiye imâmet ve tedris içün mâhiyye otuz guruş vazîfe verile ve mescid-i şerîf ve türbe-i mübâreke-i mezkûre içün senede kırk kıyye revgan-1 zeyt ve beher Ramazan-1 mübârekede iki kıyye şem'-i asel verile [...]”

ifadesi bulunmaktadır. Bu ifadeden anlaşıldığına göre Seyyid Mehmet Ağa Türbe'yi yeniden inşa ettirmiş ve yanında bulunan mescitteki imamet ve tedris görevi yapan kişiye aylık 30 kuruş ile mescit ve türbe için senede 40 okka zeytinyağı ve her Ramazan'da 2 okka bal mumu vakfetmiştir. ${ }^{8}$

Vakfiye inşa faaliyetleri tamamlandıktan sonra yazılmış olmalıdır. Seyyid Mehmed Ağa’nın vakfiyesinde müceddeden inşa edilen türbeden söz edilmekte, mescit inşasından söz edilmemektedir. Kıbrıs Evkaf Arşivi, KKTC Girne Milli Arşivi, TC Başbakanlık Osmanlı arşivinde yapılan konu ile ilgili araştırmalar sırasında tekkenin diğer binalarının önceden var olup olmadığı ile ilgili 1912 yılına kadar bir belgeye rastlanmamıştır. Kıbrıs' ın İngiliz işgali ve idaresinde bulunduğu 1912 yılında, Kutup Osman Efendi Tekkesi'nin ihtiyacı olan tamirat ile ilgili, Kıbrıs Evkaf Muhasebecisi Fahri Efendi ile Seyyid Mehmed Ağa Vakfı Mütevelli Vekili Müftüzade Hafız Şefik Efendi arasında geçen yazışmalardan, Magosa Kutup Osman Efendi Tekkesinin sadece türbe ve mescit kısmının 1824-1826 yılları arasında Kıbrıs Muhassılı El-Hac Seyyid Mehmed Ağa tarafından yaptırıldığı diğer kısımlara (dershane, iç ve dış odalar, hamam, mutfak vb.) ait herhangi bir vakfiyenin Evkaf Müdürlüğü’ nde bulunmadığı belirtilmektedir. ${ }^{9}$

1912 yılında Kutup Osman Efendi Tekkesi'nin harem kısmının tamire muhtaç olduğu tamir edilmesi için Magosa Evkaf Vekili tarafından Seyyid Mehmet Ağa Vakfı mütevellisi Hafız Şefik Efendiye yazılan dilekçelerden anlaşılmaktadır. Yapılan talep üzerine Hafız Şefik Efendi vakfiyeleri inceleyerek, türbe yanında bulunan mescit, dershane, iç ve dış odalarının Seyyid Mehmet Ağa tarafından yaptırılmadığını ancak türbenin tamirinden sorumlu olduklarını belirtmiştir. ${ }^{10}$

8 Seyyid Mehmet Ağa’nın Kıbrıs ile ilgili vakıflarını tescil ettirdiği vakfiye ve zeyiller bulunmaktadır. 19 Cemaziyülevvel 1242 (19 Aralık 1826), 3 Cemaziyülevvel 1254 (25 Temmuz 1838) ve 18 Ramazan 1256 (13 Kasım 1840) tarihli vakfiyelerin orjinalleri T.C. Vakıflar Genel Müdürlüğü Arşivinde kopyası Kuzey Kıbrıs Türk Cumhuriyeti Milli Arşiv ve Araştırma Dairesi Fetva Eminliği (MAFE) 3444 numaralı dosyada muhafaza edilmektedir. MAFE, d. 3444.

9 Kıbrıs Şeriye Sicilleri (KŞS) Defter No: 40, s. 102, Hüküm No: 116, KŞS, 47/108-177.

10 KKTC Milli Arşiv ve Araştırma Dairesi (MAFE), No: 6-48-20. 
1913 yılında Evkaf Muhasebecisi Fahri Efendi Mütevelli vekili Müftüzade Hafız Şefik Efendi'ye geçen yıl yapılan tamirat talebinin gereğinin yapılmadığından Tekke'nin harem kısmının yıkıldığını ve diğer odaların yağmurdan hasar gördüğünü bildirmiştir. ${ }^{11}$

Seyyid Mehmet Ağa Vakfı Mütevellisi Hafız Şefik Efendinin tamir dilekçesine verdiği cevaptan ve Seyyid Mehmed Ağa’nın 1826 tarihli vakfiyesinden, sadece türbe kısmının yeniden yaptırılarak vakfın kurulduğu anlaşılmaktadır. Daha önce de belirtildiği gibi çalışma kapsamında yapılan araştırmalarda, 19. yüzyıla ait arşiv belgelerinde varlığı belirlenen harem bölümü, şeyh evi, konaklama birimleri ve hamam gibi yapılardan Seyyid Mehmed Ağa vakfiyesinde söz edilmemektedir. (Ek 1, 2, 3 ve 4).

1826 yılında Seyyid Mehmed Ağa tarafından yapılan düzenlemeler ile Magosa şehrinde manevi bir mekân haline gelen Kutup Osman Efendi Türbesi ve Dergâh yapıları hayırsever kişiler tarafından yapılan vakfiyeler ile de gelişmiştir. 1828 yılında Kibrıs Muhassilı Ali Ruhi Efendi, Kutup Osman Efendi Mescidi Müderrisine ayda 10 kuruş maaş verilmesi için vakıf yapmıştır. ${ }^{12}$ Daha sonraki dönemlerde tekkede mevlit ve kuran okutulmak için, cemaate ikramda bulunmak için vakfiyeler yapılmıştır. ${ }^{13}$

Bunun yanında 1845 yılında Kıbrıs Muhassılından senelik 6094 kuruş paranın yıllık olarak tekkeye ödenmesi için alınan karar Kıbrıs Şeriye Sicillerinde mevcuttur. ${ }^{14}$ Aynı yıl tekke masrafları için Kıbrıs Mal Sandığı’ndan senelik beş yüz kuruş verilmesine dair H. 1261/M. 1845 tarihli berat KŞS 40 nolu defterin 105. sayfasında mevcuttur. Önemi günden güne artan dergâh için 1864 yılında Ayşe Dudu Hanım Hatm-i Şerif okutmak için 45 dirhem gümüş değerinde para, ${ }^{15}$ Şeyh Ömer Hüsameddin Efendi ise 7000 kuruş vakfetmiş ve Kuran, mevlit okutularak ziyaretçilere ikramda bulunması şart koşulmuştur. ${ }^{16}$ Yapılan vakıflarla gittikçe büyüyen ve 19. yüzyılda Kıbrıs'ın Hala Sultan Tekke'siyle birlikte önemli dini merkezinden biri olan, konum itibari ile Karpaz bölgesinden Larnaka'ya giden yol üzerinde bulunan dergâh, Larnaka Hala Sultan Tekkesine giden yolcuların uğradığı ve konakladığı bir mekân haline gelmiştir.

11 MAFE, 6-48-23, 6-48-24, 6-48-27.

12 Hasan Behçet, Kıbrıs Türk Maarif Tarihi (1571-1968) (Lefkoşa: MaarifYayınları, 1969), s. 35.

13 KŞS, 47/108-177.

14 KŞS, 40/105-21, 40/102-116.

15 KŞS, 41/38.

16 Şeyh Ömer Hüsameddin Efendi'nin vakfettiği para giderleri kayıt edilmiş ve ziyaretçilere yapılacak ikramın; yahni, pilav ve helva olması yönünde yapılan açıklamalar Şeriye Sicillerine kayıt ettirilmiştir. KŞS, 47/108-177. 


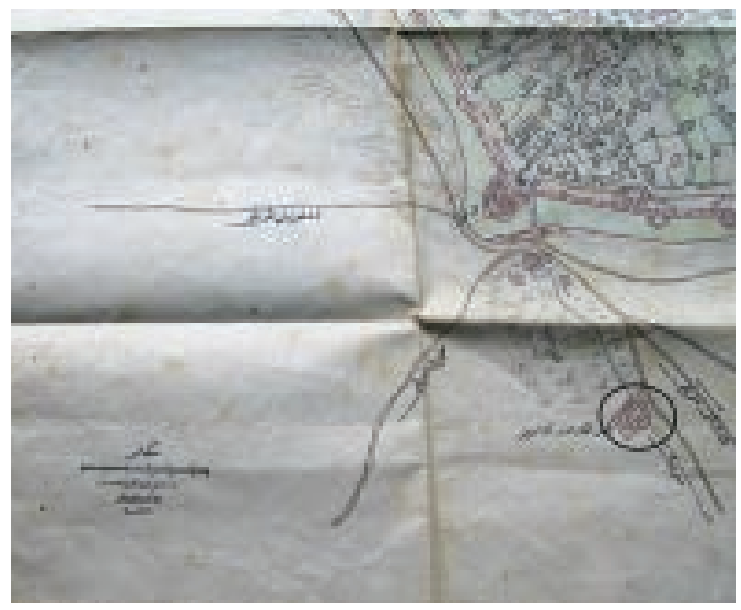

Harita 1a. 1871 Tarihli Harita (KKTC Milli Arşiv, Haritalar Dosyası).

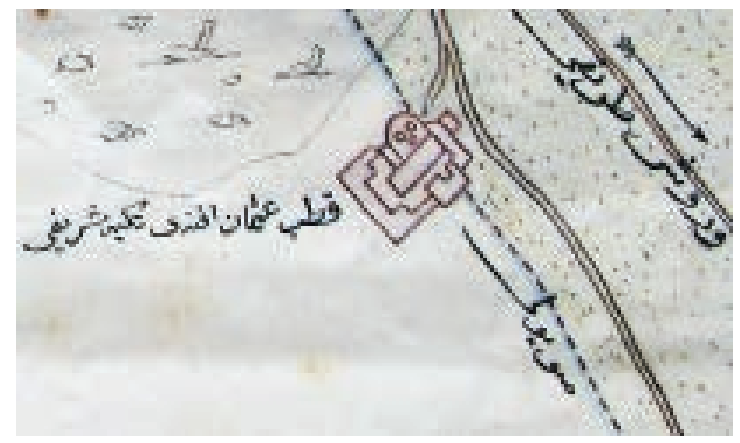

Harita 1b. 1871 Tarihli Harita Detay 1

(tekke bölümleri).

\section{Tekke Arazisi Üzerinde Var Olan Önceki Yapılara İlişkin Veriler}

Günümüzde Kutup Osman Efendi Dergâhı ya da 19. yüzyıl sonrası belgelerde Türbe ve Tekkesi olarak anılan yapılar topluluğunun bulunduğu yerde 1826 yılından önce bir tekke olduğu bilinmektedir. Fakat bu tekkenin mahiyeti ve tarih içerisinde geçirdiği değişim hakkında fazlaca bir bilgi yoktur. Tekkenin bir Mevlevî tekkesi olduğu bazı araştırmacılar tarafından ileri sürülmüştür. ${ }^{17}$

17 Gökalp Kamil'in 2010 yılında Konya Selçuk Üniversitesi organizasyonunda, Dünyada Mevlana İzleri Kongresi’nde sunulan “Dünyada Mevlana İzleri Bakışında Kıbrıs’ta Mevlevilik Geçmiş ve Şimdi” adlı bildiride tekkenin bir Mevlevî tekkesi olduğu ifade edilmiş 
Giriş bölümünde değinildiği gibi Kıbrıs’ta Türk İslâm Kültürünün yerleştirilmesi ve sürdürülebilmesi için başlatılan iskân politikasının yanı sıra derviş guruplarının üstlenmiş oldukları görevler doğrultusunda yapılan düzenlemeler, adada derviş guruplarının öncülüğüne dayalı bir iskân uygulandığının göstergesidir. ${ }^{18}$ Anadolu'dan getirilip adaya yerleştirilen halk başta Konya olmak üzere Karaman ve çevresindendir. Arap Ahmet Paşa ${ }^{19}$ tarafından 1593 yılında kurulmuş olan Lefkoşa Mevlevihanesi iskân politikaları çerçevesinde manevi alanda da bir örgütlenmenin başladığının bir göstergesi olarak kabul edilmelidir. ${ }^{20}$

H. 987 (1579) tarihli Serdar-1 Ekrem Lala Mustafa Paşa vakfiyesinde, Osmanlı imar faaliyetleri kapsamında adaya ilk kurulan tekkenin kaydı bulunmaktadır. 1573 te bizzat Sultan II. Selim Han tarafından Kıbrıs Beylerbeyi Cafer Paşaya gönderilen emirname, Lala Mustafa Paşa vakfiye ekinde yer almaktadır. Emirnamede Sultan II. Selim, Magosa şehri kuşatılırken ordunun kışladığı bölgede ahalisi kalmamış köy (hali karye) bulunduğunu, orada bulunan terkedilmiş binaların ve kilisenin sahiplerinden satın alınarak mescide dönüştürülmesini, gelen geçen (ayende ve revende) için tekke kurulmasını, hiç kimsenin malına zarar vermeden tekkenin inşa edilmesini emretmiştir. ${ }^{21}$

Osmanlı ordusunun Magosa şehrini kuşatmasını tasvir eden Astorre Baglione’nin Gravüründe (1571) günümüzde Kutup Osman Dergâhının

ancak ne basılı bildiride ne de kongre sırasında Lala Mustafa Paşa Vakfiyesi dışında kaynak belirtilmemiştir. Gökalp Kamil, "Dünyada Mevlana İzleri Bakışında Kıbrıs’ta Mevlevilik Geçmiş ve Şimdi”, Dünyada Mevlana İzleri: Uluslararası Sempozyum, 13-15 Aralık 2007 (Konya: Süsam Yayınları, 2010), s. 209.

18 Numan, "Kutub Osman Tekkesi Binaları Hakkında”, s. 345.

19 Ahmet Paşa Kıbrıs fatihlerinden olup Lefkoşa Mevlevihane’sinin kurulması için kendine ait olan Lefkoşa Kenti Girne Kapısına yakın araziyi bağışlamıştır. Yapmış olduğu bağışlardan dolayı Lefkoşa Mevlevihanesi'nin banisi sayılmakta ve bazı kaynaklarda Ahmet Paşa Mevlevihane'si olarak anılmaktadır. Lefkoşa Kentinde Arap Ahmet Paşa adına bir cami ve bir mahalle bulunmaktadır. Ayrıntılı bilgi için, Tuncer Bağışkan, Kıbrıs'ta Osmanlı-Türk Eserleri (Lefkoşa: Kuzey Kıbrıs Müze Dostları Derneği, 2005), s. 20.

20 Hasan Özönder, "Kıbrıs'ta Mevlevilik ve Mevlevihaneler”, 6. Millî Mevlâna Kongresi, 24-25 Mayıs 1992 Konya (Tebliğler) (Konya: Selçuk Üniversitesi Selçuklu Araştırmaları Merkezi, 1993), s. 99.

21 Lala Mustafa Paşa Vakfiyesi, KKTC Milli Arşiv ve Araştırma Dairesinde 3530 numaralı dosyada T.C. Emlak Dairesi Başkanlığının 4.9.1987 gün ve EM: B.1/15/1.9 sayılı yazısı üzerine yapılmış olan vakfiye tercümesi bulunmaktadır. Vakfiye ekinde bulunan emirname tarihi Evahiri Cemaziyelahir 981/1573 Ekim sonudur. VGMA, d. 746, s. 163, KKTC Milli Arşiv (MA), 3530. 
bulunduğu mevkide Osmanlı Ordusu ve iki kilise görülmektedir (Şekil 1). La Madonna De la Cava ve St. Georgio isminde iki kilise ordu birliklerinin konaklama yerine yakın konumdadır. Sultan II. Selim Han'ın emirnamesinde geçen mescide dönüştürülecek olan kilise konum itibarı ile La Madonna De La Cava Kilisesi olmalıdır. Kilisenin Magosa şehir surlarına olan konumu, üzerinde bulunduğu arazinin topografik yapısı ve tekke yapıları topluluğunun güney cephesinde görülen Osmanlı öncesi döneme ait kemer izleri bu görüşü destekleyen verilerdir (Resim 9).

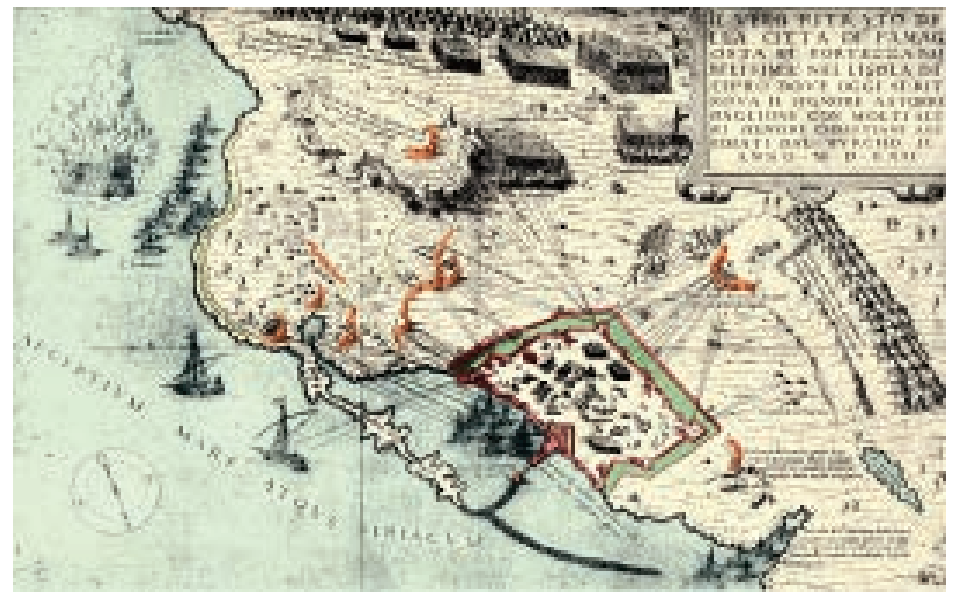

Şekil 1. Magosa Kuşatması (A. Baglione 1571). ${ }^{22}$

14. yüzyılda 'Kutsal Topraklar’a (Kudüs) ziyarete giderken Kıbrıs'a uğrayan pek çok din adamı bu iki kiliseden biri olan ve kayaya oyulmuş bir mağaradan ibaret olan Santa Maria Dela Cava Kilisesi'nden seyahat notlarında söz etmiştir. $^{23} 20$. yüzyıl başında Kıbrıs, Palestine (Filistin), Malta adası, Fiji valiliği, Batı

221571 yılında Magosa kuşatmasını Astorre Baglione detaylı olarak çizmiştir. Belgenin orijinali Paris'te Fransa Millî Kütüphanesi'nde bulunmaktadır. Bkz. Astorre Baglione (1571). Bibliothèque nationale de France (BnF), http://gallica.bnf.fr/services/engine/ search/sru? operation $=$ searchRetrieve $\&$ version $=1.2 \&$ query $=($ gallica $\% 20$ all $\% 20 \% 221$ e $\% 20$ si\%C3\%A8ge\%20de\%20Famagouste\%22) (Erişim 10 Ocak 2018).

231335 yılında Kudüs'e haç ziyareti yapmak için yola çıkan Augistina keşişi Jacobus de Verona yolu üzerinde olan Kıbrıs'ta 20 gün kadar kalır. 1 Temmuz 1335 günü Magosa şehrinden 2 ok atımı uzakta olan S. Maria de la Cava Kilisesini hacca gidenler, tüccarlar ve denizciler ile birlikte ziyaret ederek mum yakıp dua ettiklerinden bahsetmektedir. Bkz. Claude Delaval Cobham, Excerpta Cypria'dan Magosa Yazıları (M.Ö. 66-M.S. 1772), çev. Ata Atun (Magosa: Samtay Vakfi Yayınları, 2002), s. 134. 
Pasifik Yüksek Komiserliği yapmış olan Harry Luke ${ }^{24}$ bu konuda bilgiler içeren pek çok yayın yapmışır. Bu yayınlar içerisinden Kıbrıs ile ilgili olanlar Claude Delaval Cobham (1866) ve Theophilus A. H. Mogabgab (1941) tarafından 1945 tarihlerinde ilavelerle yayınlanmıştır. ${ }^{25}$ Bu yayınlarda, kilise ile ilgili olarak 1335 yılında Kıbrıs'ı ziyaret edip 20 gün kalan İtalyan din adamı Jacobus de Verona’nın gezi notlarında Santa Maria de la Cava hakkında bilgiler mevcuttur. ${ }^{26}$ Jacobus, Magosa şehrine gelen herkesin ziyaret ettiği önemli bir kutsal mekân olan Santa Maria de la Cava/La Madonna De la Cava Kilisesi'nin, Magosa şehrinden iki ok atımı uzakta, 36 basamakla inilen bir mağara içerisinde olduğunu anlatmaktadır. ${ }^{27}$

Bir başka gezgin, 1394 yılında Magosa’yı ziyaret eden Nicolai de Marathono Magosa şehri dışında bir köyden bahsetmektedir. Köyde bulunan çok sayıda evin durumunun harab olduğundan ve orada kimsenin yaşamadığından söz eden Marathono aynı mahalde S. Maria isminde mağara kilisesinin varlığını notlarına kaydetmiştir. ${ }^{28}$

14. yüzyıla ait Kudüs'ü ziyarete giden rahiplerin seyahat notlarından önemli bir ziyaret yeri olan Magosa'daki St. Maria de la Cava isimli kilisenin yanında içinde Katolik papazların sürekli yaşadığı yapılar olduğu anlaşılmaktadır. ${ }^{29} \mathrm{Bu}$ bilgilerden yola çıkılarak Osmanlıların adayı fethinden önce burada rahiplerin yaşadığı küçük manastır niteliğinde yapılar olduğu söylenebilir. Resim 6 da görülen revak kemerlerinin arasındaki sütunların üslubu yapıların diğer bölümlerinden daha eskidir. Bu konuda kesin bir şey söyleyebilecek birincil kaynak olmayışından ötürü kesin bir yorum yapılamasa da tüm veriler bir araya getirildiğinde, 16. yüzyıl öncesi var olan yapıların (kilise ve rahiplerin yaşadığı mekânlar) güney kanadında ve günümüzde Namık Kemal Lisesi derslik binalarının yerinde bulunduğu söylenebilir. İngiliz döneminde’de (1894) tekkede yapılan geniş bir tamirat sonrasında

24 Harry C. Luke, Cyprus (Nicosia: George G. Harrap\&Kemal Rüstem, 1965), s. 138.

25 Theophilus A. H. Mogabgab, Supplementary Excerpts on Cyprus: Kıbrıs Yazılarına Ek (MÖ 522 - MS 1581) (Lefkoşa: Galeri Kültür Yayınları, 2014), s. 81; Cobham, Excerpta Cypria'dan Magosa Yazıları, s. 83.

26 Ayrıntılı bilgi için bkz. Mogabgab, Supplementary Excerpts on Cyprus, s. 106.

27 Cobham, Excerpta Cypria'dan Magosa Yazılar, s. 135.

28 Ata Atun, Milat Öncesinden Günümüze Kıbrıs Tarihi Üzerine Belgeler (Magosa: Samtay Vakfi Yayınları 2005), s. 121.

29 Cobham, Excerpta Cypria'dan Magosa Yazılar, s. 21. 
doldurulduğu anlaşılan avluda ${ }^{30}$ yapılacak araştırma ve sondaj kazıları bu konuda kesin bir söz söylemeye olanak sağlayacaktır.

$\mathrm{Bu}$ bilgiler bir araya getirildiğinde; Lala Mustafa Paşa vakfiyesinde geçen, içinde kilisesi olan ahalisi kalmamış köyün (hali karye) Marathono'nun notlarında adı geçen St. Maria Della Cava Kilisesinin içinde bulunduğu harap durumdaki köy olduğu düşüncesini akla getirmektedir. Baglione gravüründe La Madonna De La Cava kilisesi tepe üzerinde bazilika planlı bir yapı olarak gösterilmiştir (Şekil 2). Vakfiyede sözü geçen kimsenin hakkına zarar gelmeden mescide dönüştürülen kilise Baglione'nin gravüründe görülen La Madonna de la Cava/St. Maria de la Cava olmalıdır. Gravürde bir tepe üzerinde bir şapel bir de tepenin ağzında bir kapı görünmektedir. Bu kapı, bir mağara içerisinde olduğu Marathona ve Jacobus de Verona’nın 1335 tarihli notlarında belirtilen St. Maria Dela Cava’nın (Mağaradaki Meryem) kapısı olmalıdır.

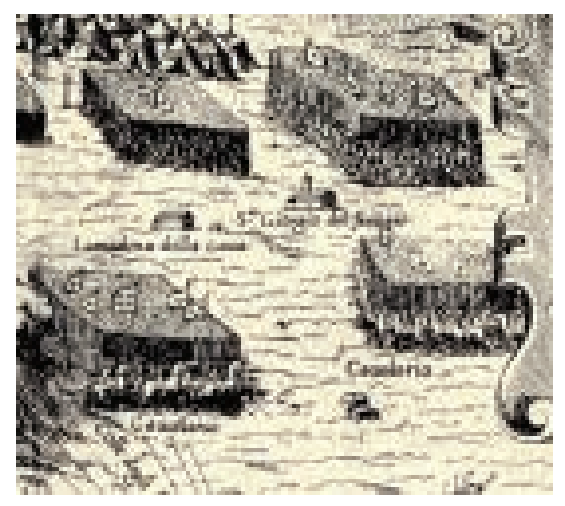

Şekil 2. La Madonna de la Cava ve St. Georgio del Faragio kiliseleri Detay, (A. Baglione 1571).

30 Kıbrıs Vakıflar İdaresi tekkede yapılan tamirlerin detayları ile birlikte rapor edildiği metraj listesi mevcuttur. Taş, mertek, toprak, kamış, saman, çimento, alçı, kireç gibi harcama kalemleri belirtilmiş bunun yanında ustalar için yapılan ödeme miktarları rapor edilmiştir. Bkz. KVİ., d. 67/1619. 


\section{Değerlendirme}

Kuşatma sırasında çizilen gravürlerden Kıbrıs'ta yaptırılan ilk Osmanlı tekkesinin günümüzde Kutup Osman Efendi Tekkesi adı ile bilinen tekkenin yerinde olduğu anlaşılmaktadır. ${ }^{31}$

Tekke yapılarının işaretlenmiş olduğu en eski harita H 1288/M 1871 tarihli Osmanlı döneminde mühendis Muhammed Ali’nin çizdiği haritadır (Harita 1a ve 1b). Bu haritada Dergâh, Magosa sur dışında Akkule kapısı karşısında bulunan Müslüman Mezarlığının güney ucunda görülmektedir. Yine aynı haritada Cafer Paşa Su kemerlerinin dergâh içerisinden geçip Magosảya devam ettiği görülmektedir. ${ }^{32}$ Seyyid Mehmet Ağa’nın yaptırmış olduğu düzenlemeleri de içeren haritada mevcut şemadan, türbenin bulunduğu kuzey, doğu, batı ve güney bölümlerinin birbirleri ile ilişkili olduğu anlaşılmaktadır.

Dergâh yapılarının batı kanadını oluşturan bölümde önceden var olduğu anlaşılan ve zamanla kaybolan birtakım yapılar 1882 tarihli Kitchener haritasında ve sonraki dönemlere ait haritalarda da izlenmektedir (Harita 2 ve 3). Dergâh yapılarına ait olup günümüze ulaşamadığı düşünülen yapılara ait kalıntılardan biri, güney cephesinde izlenen içi doldurulmuş Gotik kemerdir (Resim 9). Bu kemerli giriş ve kemerin bulunduğu cephe düzeni incelendiğinde eski çatı izleri halen görülmekte olup, Şekil 2 de görülen beşik çatıya sahip St. Maria Dela Cava kilisesinden kalan parçalar olduğunu düşündürmektedir.

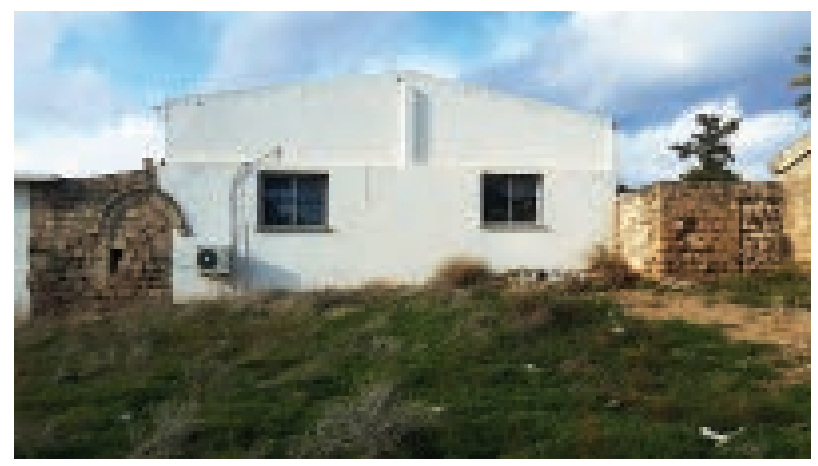

Resim 9. Güney Kanadında Gotik Kemer Kalıntıları

(M. Eyyamoğlu).

31 Bkz. Şekil 1.

32 Netice Yıldız, "Aquaducts in Cyprus”, Kıbrıs Araştırmaları DergisilJournal for Cypriot Studies, II/2 (1996), s. 89. 


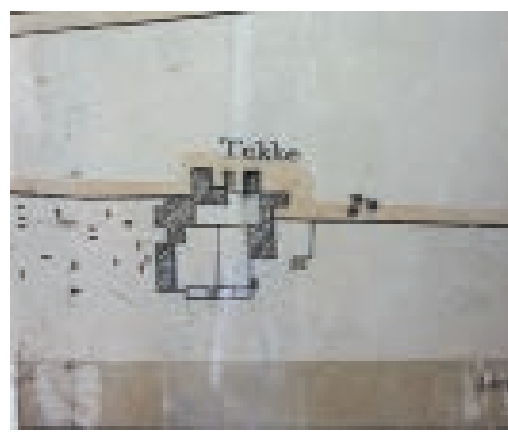

Harita 2. 1882 Yilı Tekkenin

Durumunu Gösterir Harita

(Kitchener 1882).

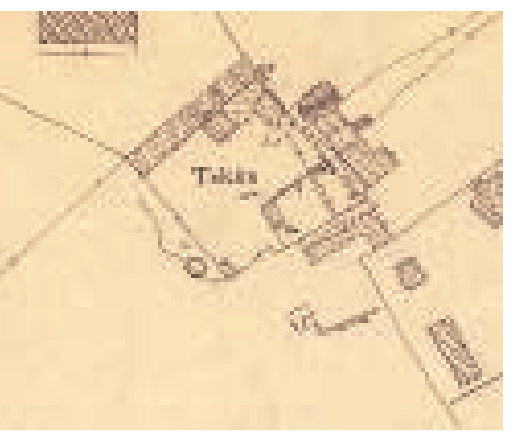

Harita 3. 20. Yüzyıl Başı (1929)

Tekke Planı KKTC Harita Dairesi

(XXXIII.12.5.II).

Bu tespitler, daha önce anlatıldığı gibi, Lala Mustafa Paşa vakfiye ekinde bulunan Sultan II. Selim Han'ın emirnamesinde geçen kiliseye ait olduğu düşüncesini güçlendirmektedir.

1878 yılındaki İngiliz işgalinden sonra arşivlerde bulunan yazışmalardan tekke binalarına onarım için gereken ödemelerin yapılmadığı, tekkenin harem kısmının bakımsızlıktan çöktüğü anlaşılmaktadır (Ek 1 ve 2). Tamir talebinin reddedilmesinden dolayı 1913 tarihinde tekke harem bölümünün sundurmasının yağmurdan dolayı yıkıldığı, diğer odaların ise hasar gördüğü Magosa Evkaf Vekili Hasan Hilmi Efendi'nin Lefkoşa İngiliz Evkaf İdaresi'ne yazdığı raporlarda bildirilmiştir. ${ }^{33}$ Eski tarihli haritaların tümünde izlenen avluyu işlevlerine göre ayıran duvarlar ve avluda bulunan çeşme 2005 yılında yapılan düzenleme ve tadilatlar sırasında kaldırılmıştır (Resim 9).

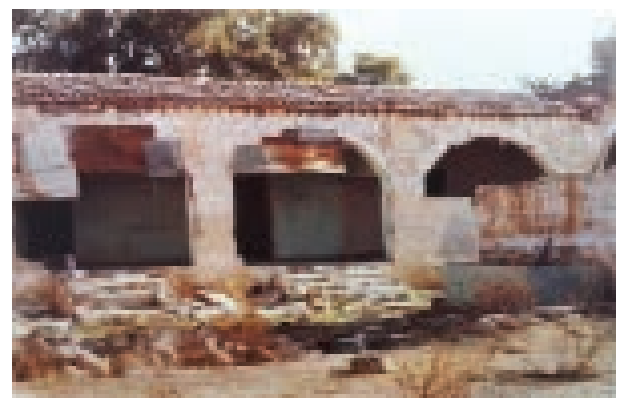

Resim 9. Avluda Bulunan Duvar ve Çeşme (Magosa Halk Kütüphanesi). 
20. yüzyıl başlarına kadar asli işlevini sürdüren Kutup Osman Efendi Tekke ve Türbesi, vakıf gelirlerinin kesilmesi görevlilerine maaş ödenmemesi nedeni ile işlerliğini yitirmiştir. Çalışma kapsamında incelenen eski harita ve arşiv belgeleri ışığında özellikle batı kanadında var olduğu belirlenen yapıların 19. yüzyıl sonlarında yıkılmış olduğu düşünülmektedir.

1932 yılına ait vakıf dosyalarında tekke binalarında bulunan arka odaların mutfağa dönüştürülmüş, mermerlerin sökülerek mekânlar arası geçişlerin kapatılmış işlev ve fonksiyonların tamamen değiştirilmiş olduğu bilgileri mevcuttur. ${ }^{34}$ II. Dünya Savaşı'nın devam ettiği 1940 yılında, Dergâh Magosa Hastahanesi karşısında olduğu gerekçesiyle İngiliz Yönetimince adaya getirilebilecek olan yaralı askerler için boşalttırılmışırı. ${ }^{35}$ Tekkede görevli son şeyh Osman Nuri Efendi'nin 1943 yllında vefat etmesinden sonra yeni bir şeyh atanmamış binalar atıl vaziyette kalmıştır (EK 4 ve 5). 1949 Yılında Namık Kemal Lisesinin Tekke binalarına taşınması ile Kutup Osman Efendi Tekkesi binalarının tamamen işlevi değiştirilmiştir. Günümüzde kuzey kanattaki Türbe, mescit kısmı ziyaret amaçlı, doğu kanadı halk kütüphanesi, batı kanadı tuvalet ve Namık Kemal Lisesi dersliği, güney kanadındaki revaklı kısım ise kütüphane deposu olarak kullanılmaktadır.

\section{Sonuç}

İlk inşasının 19. yüzyıl öncesine dayandığı Lala Mustafa Paşa Vakfiyesinden anlaşılan Magosa Kutup Osman Efendi Türbe-Tekke/Dergâh yapılarının, mekân örgütlenmesi, plan ve cephe düzeni açısından, günümüze ulaşabilmiş yapıların özgün durumlarına ilişkin parçaların azlı̆̆ı ve yapılara ilişkin birincil kaynak bulunamaması sebebi ile kesin bir yorum yapılamamaktadır. Gerek 16. yüzyılda gerekse 19. yüzyılda kuruluş ve geliştirilmesinde devlet desteği olduğu açıkça belirgin olan tekke, 1878 İngiliz İşgali sonrası yaşanan siyasal gelişmeler neticesinde ifa ettiği asli görevi icra edemeyecek duruma gelmiştir. Çalışma kapsamında yapılan araştırmalarda Ada'nın fethinde ordu komutanı olan Lala Mustafa Paşanın Sultan II. Selim Han emri ile Cafer Paşa'ya yaptırmış olduğu belirlenmiş olan tekkenin 19. yüzyıl öncesindeki durumu net olarak tespit edilememektedir.

17. yüzyılın önemli Halveti-Celveti şeyhlerinden Kutup Osman Efendi adına bir Celveti saray mensubu olan Muhassıl El-Hac Seyyid Mehmed Ağa eli ile 
ölümünden yaklaşık 135 yıl sonra türbesinin inşası ve çevresinin yeniden düzenlenmesi sonucu tekke yeniden işlevsel hale gelmiştir. Zaman içerisinde geçirdiği değişimler mekân-işlev münasebetinin saptanmasını zorlaştırır durumda olsa da Tekke bünyesinde günümüze ulaşamayan mekânların var olduğu, bir kısmının günümüze bölünerek, gömülerek ulaştığı açıktır. Tekke yapılarının diğer önemli problemi, oldukça geniş olan arazisinin parçalanmış olmasıdır. Tekke bitişiğinde var olan mezarlık alanı İngiliz İdaresi Dönemi'nde kaldırılmış, mezarlık arazisi üzerinde Namık Kemal Lisesi inşa edilmiş tekke ve mezarlık arazi sınırları tamamen değiştirilmiştir.

Yapı ile ilgilenen araştırmacılar tekke binalarının kuruluşunu 19. yüzyıla ve Seyyid Mehmet Ağa’ya dayandırsada önceden tekke arazisi üzerinde 16. yüzyılda Cafer Paşa eli ile yaptırtılmış bir tekke'nin var olduğu gerek arşiv belgelerinden gerekse binalar üzerinde rastlanan izlerden anlaşılan bir gerçektir. Dergâh dâhilinde bulunan yapılar arasında gözlenen seviye farklılıkları, duvar örgü teknikleri günümüze ulaşan yapıların farklı dönemlerde inşa edildiğini göstermektedir.

Sonuç olarak; 16. yüzyılda kurulan, 19. yüzyılda yenilenerek geliştirilen Osmanlı/Türk-İslâm Kültürü’nün Kıbrıs'taki önemli temsilcisi ve yayıcısı olan Kutup Osman Efendi Tekkesi/Dergâhı günümüze İngiliz İsgali sonrası Kıbrıs’ın yaşadığı siyasi çalkantılar sonucu özgün mimari kimliği ve işlevi ile ulaşamamıştır. Daha önce var olan fakat günümüze ulaşamamış yapıların saptanarak mekân işleyişinin tanımının yapılabilmesi için binalar çevresinde, özellikle bugün doldurulmuş vaziyette olan avluda ve batı kanadında kazı çalışmaları gerekmektedir.

Kıbrıs’ta Osmanlı tasavvuf kültürünün yaygınlaştırılması için kurulmuş ilk sosyal merkezlerden biri olan ve bu görevini 20. yüzyıla dek sürdürmüş bulunan Kutup Osman Efendi Türbe ve Tekkesi Kıbrıs'n önemli dini, kültürel, sosyal, tarihi merkezlerinden biridir. 19. yüzyıldaki tüm olanaksızlıklara rağmen tarihsel manevi varlığını sürdüren yapılar topluluğu daha ayrıntılı ve özenli araştırmaları, restorasyonları hak etmektedir. 


\section{Ekler:}

\section{Ek 1:}

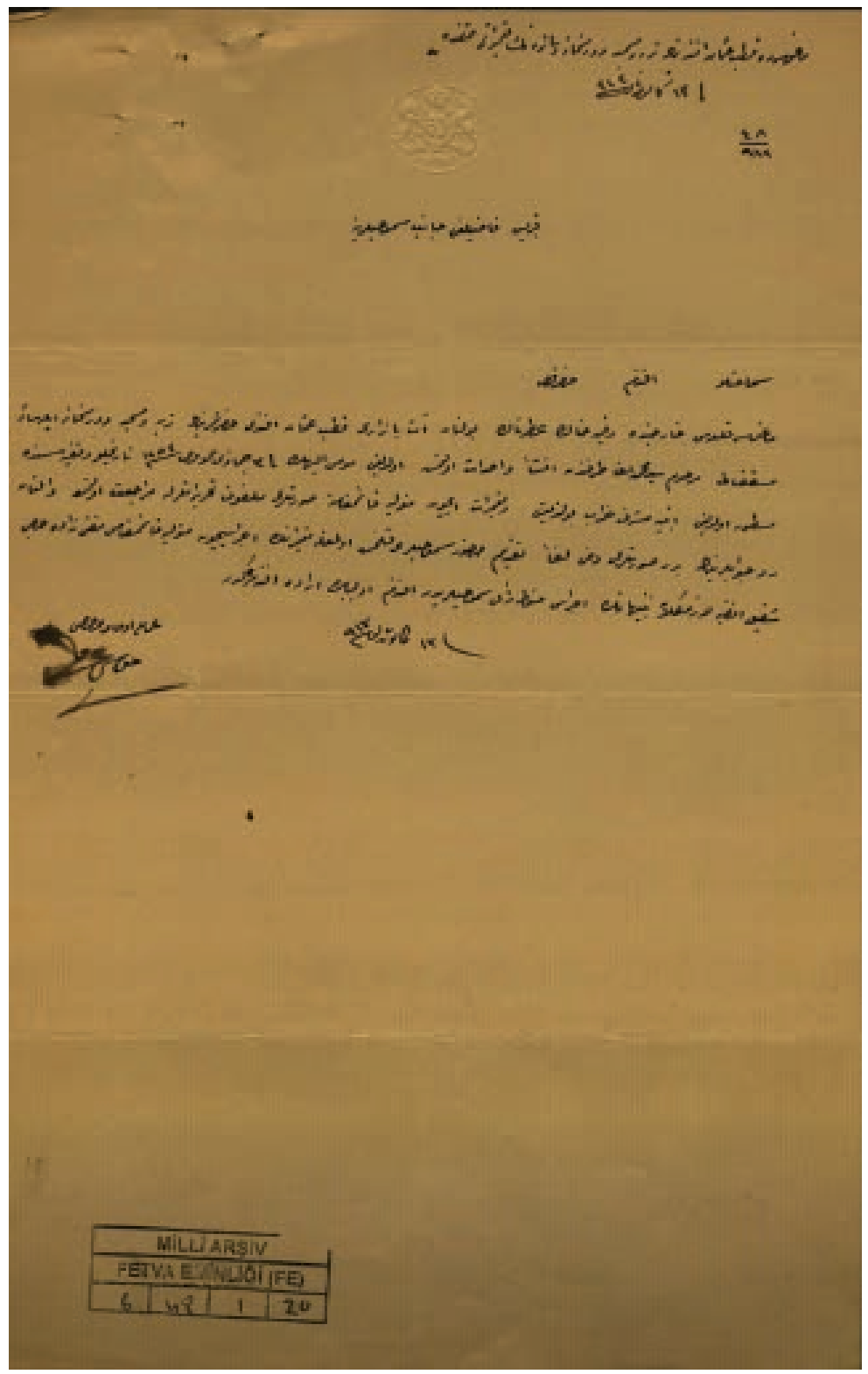

Seyyid Mehmet Ağa vakfı mütevellisi Müftüzade Hacı Şevki Efendi'ye gelen tamir talebi ile ilgili yazı, MAFE, 6-48-1-20. 


\section{EK 2:}

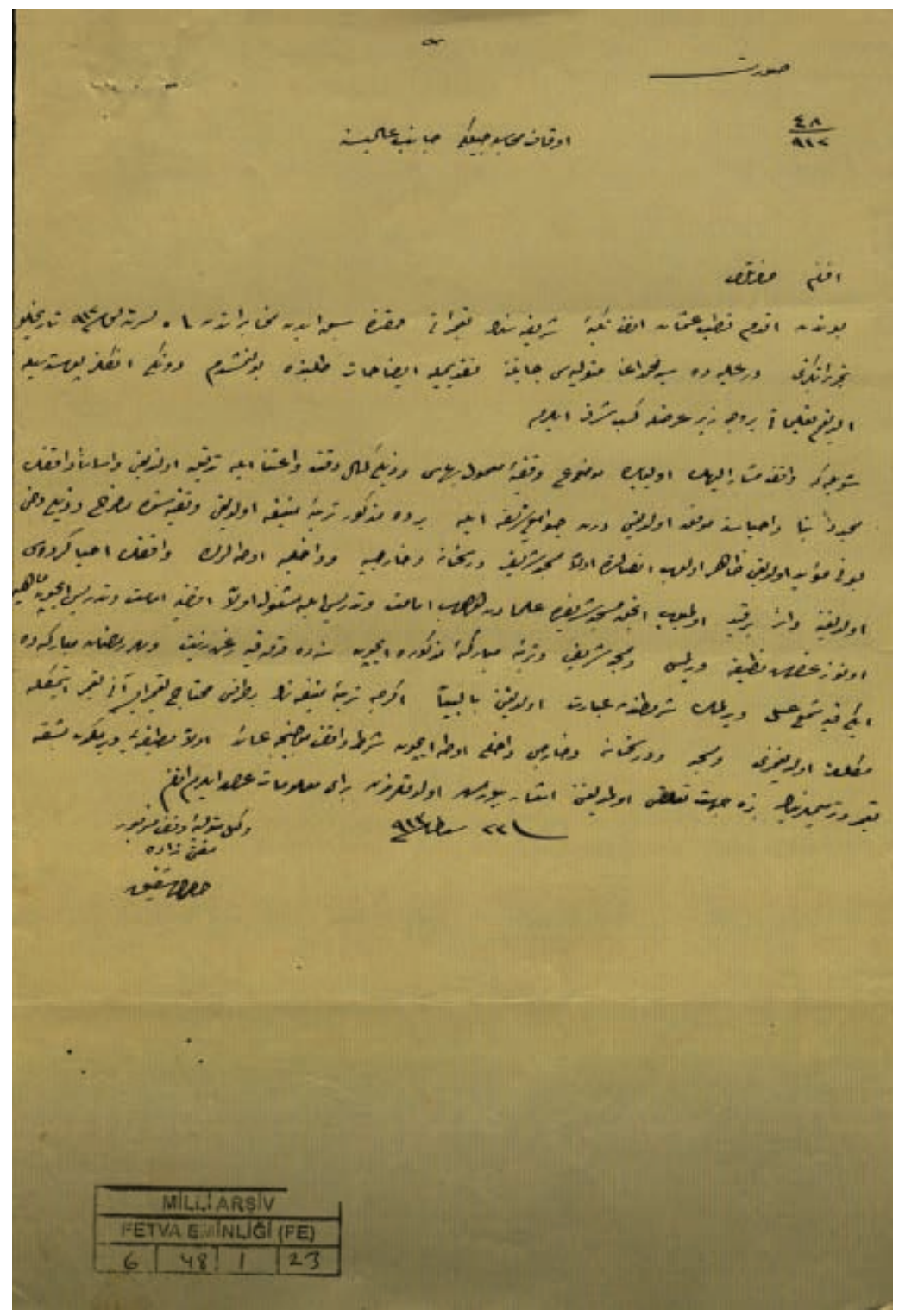

Seyyid Mehmet Ağa tarafından sadece türbe kısmının yeniden yaptırılarak vakıf kurulduğu yanında bulunan mescit, dershane, iç ve dış odaların vakfa dâhil olmadığı ile ilgili yazı. MAFE, 36-48-1-23. 


\section{Ek 3:}

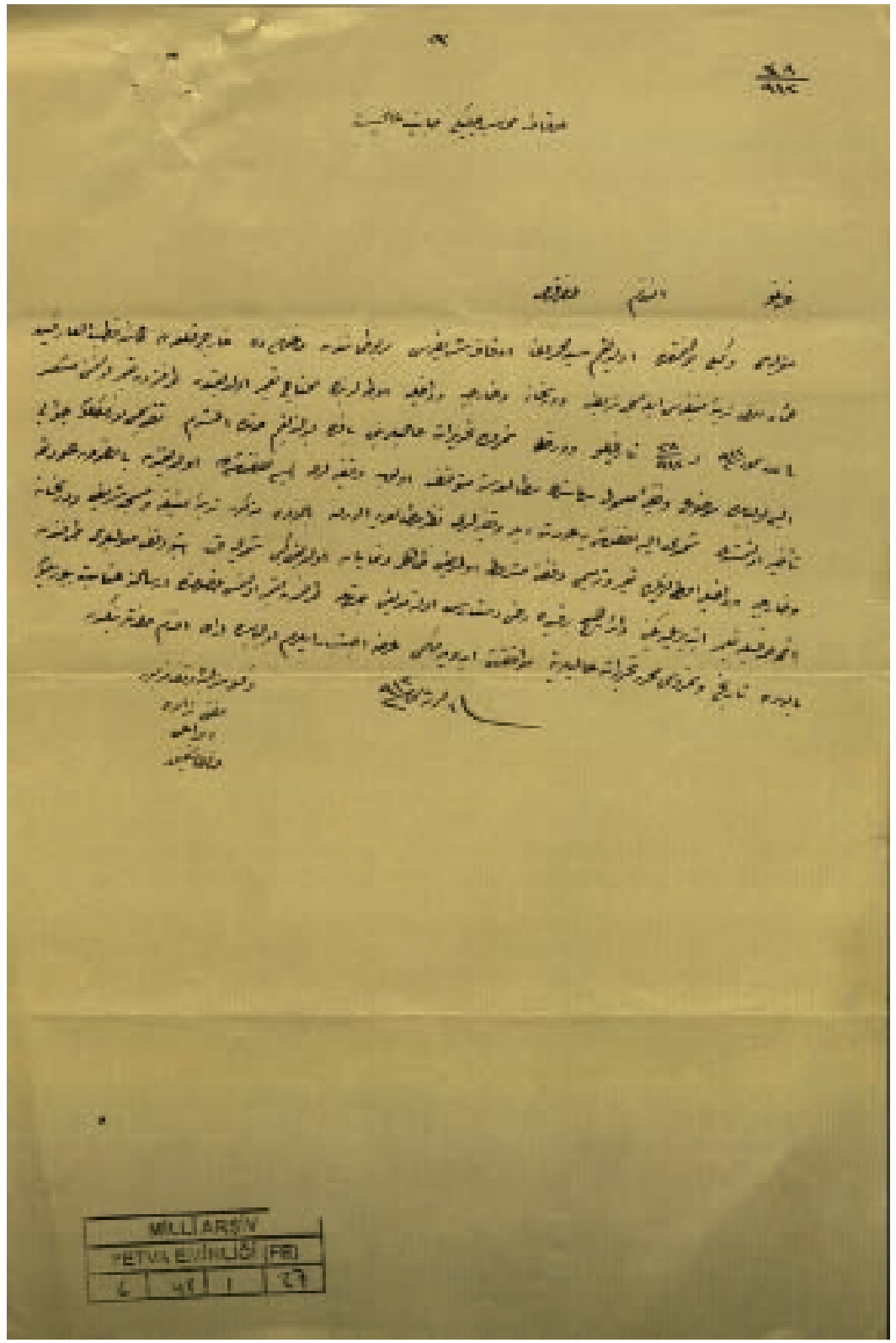

Vakfa dâhil olmayan Tekke dershane dış ve iç odaların tamir talebinin ret edildiği ile ilgili yazı. MAFE, 6-48-1-27. 
Ek 4:

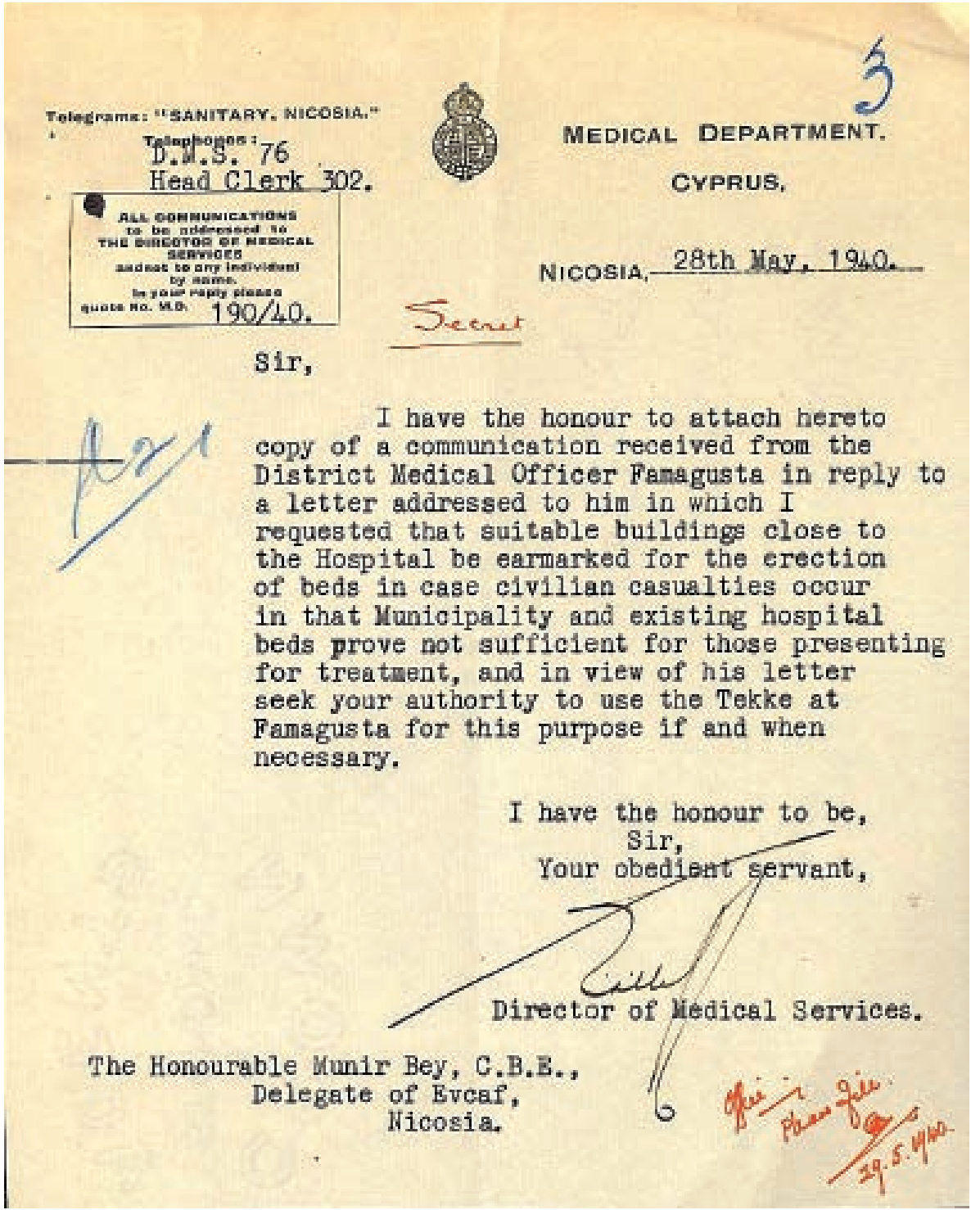

Tekke binalarının hastane olarak kullanılması ile ilgili yazı. KVİ, 343/7046/3. 


\section{Ek 5:}

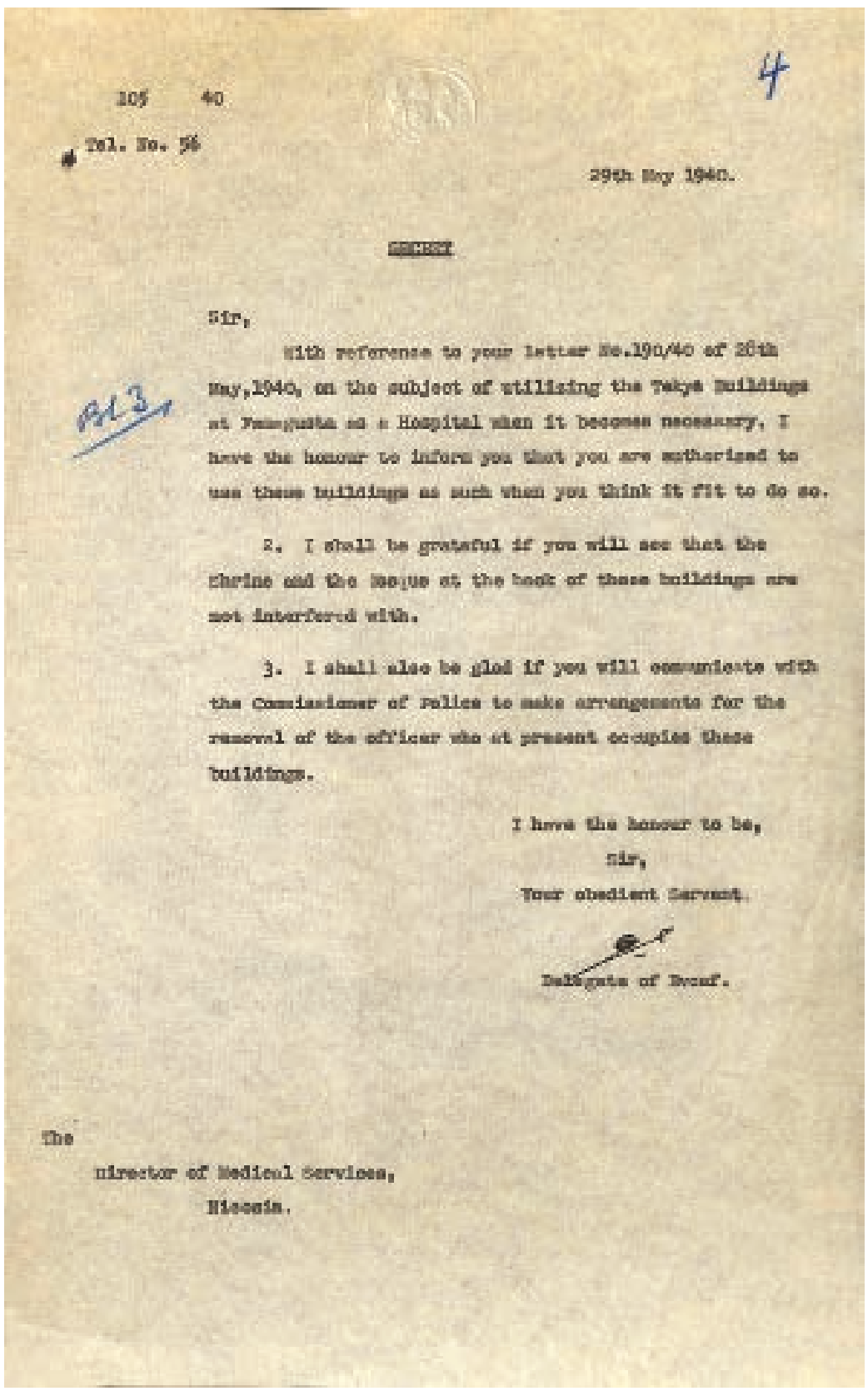

Tekke binalarının boşaltılması ile ilgili yazı. KVİ,343/7046/4. 
Öz — Bu makalede bugün Kuzey Kıbrıs Türk Cumhuriyeti'nde Magosa sur dışında bulunan Kutup Osman Efendi Dergâhına ilişkin mevcut arşiv belgeleri, gravür, haritalar ve yakın dönem araştırmaları değerlendirilerek dergâhın tarihsel süreçte geçirdiği değişiklikler belirlenmeye, mevcut araştırmalarda yer almayan 19. yüzyıl öncesi dergâhı hakkında tespitler yapılmaya çalışılmıştır. Osmanlı coğrafyasının muhtelif bölgelerine gönderdiği ve aralarında İsmail Hakkı Bursevi'nin de olduğu 150 kadar halifesi ile 17. yüzyıl Celvetiliği'nin dikkat çeken simalarından biri olan Atpazarî Osman Fazlı Efendi (1632-1691) İstanbul siyasi hayatında önemli bir yer edinmiş ve zaman zaman siyasete müdahaleleri dolayısıyla da sürgün edilerek son sürgün yeri olan Magosa'da 1691 yılında vefat etmişti. Magosa kalesi sur dışında bulunan Osmanlı Mezarlı̆̆ı gerisine defnedilen Celvetiliğin bu önemli simasının zamanla kaybolan kabri yine bir Celveti olan saray kapıcıbaşılarından ve Kıbrıs’a muhassıl olarak atanan Seyyid Mehmet Ağa tarafından 19. yüzyıl başlarında bulunarak kendisi için bir türbe yapılmıştır. Seyyid Mehmet Ağa’nın yaptırdığı Kutup Osman Efendi Türbesinden vakfiyelerinde söz edilmiş olmasına rağmen bitişiğinde bulunan mescidin bina edildiği belirtilmemiş, daha önceden aynı yerde bir tekke/dergâh olduğundan da söz edilmemiştir. Çalışma, türbe ve etrafındaki yapılar topluluğunun tarihteki izlerini sürmekte ve Kıbrıs'ın fethinden itibaren geçirdiği değişimi incelerken yüzlerce yılda oluşmuş olan arkeolojik/kültürel katmanların çözümlemesini yapmakta Hristiyan kutsal mekânlarının İslâmlaştırılması ve dönüşümü sonucu ortaya çıkan yeni kültürel mekânları incelemektedir.

Anahtar kelimeler: Kıbrıs, Kutup Osman Efendi Tekkesi, Osmanlı Mirası, Kıbrıs'ta Türk Kültürü, 19. Yüzyıl Kıbrıs'ta Osmanlı Mimarlığı.

\section{Bibliyografya}

\section{Arşiv Belgeleri}

\section{Kıbris Vakıflar İdaresi (KVİ)}

KVİ., Dosya no. 67 Gömlek no. 1619.

KVİ., Dosya no. 343 Gömlek no. 7046.

\section{Kıbrıs Şerr'i Sicil Defterleri (KŞS.):}

KŞS, Defter no: 40, Sayfa 102, Hüküm 116.

KŞS, Defter no: 40, Sayfa 105, Hüküm 21.

KŞS, Defter no: 47, Sayfa 108, Hüküm 177. 


\section{Kuzey Kıbrıs Türk Cumhuriyeti Milli Arşiv ve Araştırma Dairesi (MA):}

\section{Fetva Emenliği (FE.)}

MAFE, 2-18-29-1.

MAFE, 2-18-29-2.

MAFE, 6-48-1-20.

MAFE, 6-48-1-23.

MAFE, 6-48-1-24.

MAFE, 6-48-1-27.

MAFE, 27-16-5-2.

\section{Vakıflar Genel Müdürlüğ̈̈ Arşivi (VGMA)}

VGMA, Defter No.746.

VGMA, Defter No.989.

\section{Haritalar}

Astorre Baglione (1571). Bibliothèque nationale de France (BnF), http://gallica.bnf.fr/ services/engine/search/sru? operation $=$ searchRetrieve \&version $=1.2 \&$ query $=($ galli ca $\% 20$ all $\% 20 \% 22$ le $\% 20$ si $\%$ C3\%A8ge\%20de\%20Famagouste\%22) (Erişim 10 Ocak 2018).

Captain H. H. Kitchener (1882). K.K.T.C. Milli Arşiv ve Araştırma Dairesi- Girne. KKTC Harita Dairesi, Pafta No: XXXIII. Parsel No: 12.5.II.

Osmanlı Dönemi Magosa Haritası (1871). K.K.T.C. Milli Arşiv ve Araştırma Dairesi- Girne.

\section{Yayınlanmış Eserler}

Acar, Türkân: “Tabhaneli Camilerin Tipolojisi Üzerine Bir Deneme”, Süleyman Demirel Üniversitesi Fen Edebiyat Fakültesi Sosyal Bilimler Dergisi, 208 (2003), s. 303-326.

Akar, Metin: "Kutup Osman Efendi ve Kıbrıs'ta Bıraktığı İzler”, 1. Uluslararası Türk Dünyası Eren ve Evliyaları Kongresi Bildirileri, Ankara: Ervak Yayınları 1998, s. 29-42.

Akozan, Feridun: “Türk Külliyeleri”, Vakıflar Dergisi, 8 (1969), s. 303-308.

Altan, Mustafa Haşim: Belgelerle Kıbrıs Türk Vakıflar Taribi, Lefkoşa: Vakıflar İdaresi Yayınlar1 1986.

Aslanapa, Oktay: Kıbrısta Türk Eserleri, Ankara: T.C. Kültür Bakanlığı, 1975.

“Atpazarlı Osman Fadlı Efendi”, Evliyalar Ansiklopedisi, X (Ankara 2000), s. 217. 
Atun, Ata: Milat Öncesinden Günümüze Kıbrıs Tarihi Üzerine Belgeler, Magosa: Samtay Vakfi Yayınları 2005.

Bağışkan, Tuncer: Kıbrıs'ta Osmanlı-Türk Eserleri, Lefkoşa: Kuzey Kıbrıs Müze Dostları Derneği 2005.

Baykara, Tuncer: "Yeni Çeri Ocağının Kaldırılması ve Sosyal Sonuçları", Sultan II. Mahmud ve Reformları Semineri İstanbul, 28-30.VI.1989, İstanbul: İstanbul Üniversitesi Edebiyat Fakültesi Basımevi 1990, s. 147-155.

Bedirhan, Muhammet: Osman Fazlî Atpazarî: Hayatı-Eserleri ve Tasavvufî Görüşleri (Yayımlanmamış Yüksek Lisans Tezi) İstanbul: Marmara Üniversitesi, 2001.

Behçet, Hasan: Kıbrıs Türk Maarif Tarihi (1571-1968), Lefkoşa: Maarif Yayınları 1969.

Beratlı, Nazım: Kıbrıslı Türkler’in Kökenleri ve Kıbrıs'ta Bektaşilik, İstanbul: Kalkedon Yayincilik 2008.

Cobham, Claude Delaval: Excerpta Cypria'dan Magosa Yazıları (M.Ö. 66-M.S. 1772), çev. Ata Atun, Magosa: Samtay Vakfi Yayınları 2002.

Gazioğlu, Ahmet: Kıbrıs Türk Tarihi: Türk Dönemi (1570-1878), Lefkoşa: Kıbrıs Araştırma ve Yayın Merkezi 1995.

Jeffrey, George: Historic Monuments of Cyprus, Nicosia: William James Archer 1918.

Kamil, Gökalp: “Dünyada Mevlana İzleri Bakışında Kıbrıs'ta Mevlevilik Geçmiş ve Şimdi”, Dünyada Mevlana İleri: Uluslararası Sempozyum, 13-15 Aralık 2007, Konya: Süsam Yayınları 2010, s. 209-220.

Köprülü, Mehmet Fuad: Türk Edebiyatında İlk Mutasavvıflar, Ankara: Diyanet İşleri Başkanlığı Yayınları 1991.

Kutup Osman Efendi Tekkesi Kitabesi, Cambulat Müzesi, Muğusa, Kuzey Kıbrıs Türk Cumhuriyeti.

Luke, Harry C.: Cyprus, Nicosia: George G. Harrap\&Kemal Rüstem 1965.

Luke, Harry C.: Türk İdaresinde Kıbrıs 1571-1878, Lefkoşa: Galeri Kültür Yayınları 2014.

Mogabgab, Theophilus A. H.: Supplementary Excerpts on Cyprus: Kibrıs Yazılarna Ek (MÖ 522 - MS 1581), Lefkoşa: Galeri Kültür Yayınları 2014.

Namlı, Ali: İsmail Hakkı Bursevi ve Tamâmü-l Feyz Adlı Eseri (Yayımlanmamış Yüksek Lisans Tezi) İstanbul: Marmara Üniversitesi, 1994.

Namlı, Ali: "İsmaîl Hakkı Bursevî", TDV İslâm Ansiklopedisi, XXIII (Ankara 2001), s. $102-106$.

Numan, İbrahim: "Kutub Osman Tekkesi Binaları Hakkında", Sanatta Anadolu-Asya İlskileri: Prof.Dr. Beyhan Karamă̆araliya Armă̆an, Ankara: Hacettepe Üniversitesi Yayınları 2006, s. 345-358. 
Özönder, Hasan: "Kıbrıs'ta Mevlevilik ve Mevlevihaneler", 6. Millî Mevlâna Kongresi, 2425 Mayıs 1992 Konya (Tebliğler), Konya: Selçuk Üniversitesi Selçuklu Araştırmaları Merkezi 1993, s. 99-117.

Özer, Ekrem: Osmanlida Tekke ve Tarîkat Islahâtları: II. Mahmud Dönemi ve Sonrası (Yayımlanmamış Doktota Tezi) Erzurum: Atatürk Üniversitesi, 2007.

Özkul, Ali Efdal: Kibris'ta Osmanlı İzleri/Traces of Ottoman Era in Cyprus, Lefkoşa: Kıbrıs Türk Yazarlar Birliği 2014.

Seager, M. Captain: Reports on the Evcaf Properties, Nicosia: British Dalegates Cyprus 1883.

Tanman, M. Baha: "Eyüpsultan'da Tarikat Yapıları", 1. Eyüpsultan Sempozyumu: Tebliğler, İstanbul: Eyüp Sultan Belediyesi Kültür Yayınları 1997, s. 102-120.

Yıldız, Netice: "Aquaducts in Cyprus", Kıbrıs Araştırmaları DergisilJournal for Cypriot Studies, II/2 (1996), s. 89-111.

Yıldız, Sakıb: "Atpazarî Osman Fazlı”, TDV İslâm Asiklopedisi, IV (Ankara 1991), s. 83-85. 